\title{
Observations of $\mathrm{NO}_{\mathrm{x}}, \Sigma \mathrm{PNs}, \Sigma \mathrm{ANs}$, and $\mathrm{HNO}_{3}$ at a Rural Site in the California Sierra Nevada Mountains: summertime diurnal cycles
}

\author{
D. A. Day ${ }^{1, *}$, D. K. Farmer ${ }^{1, * *}$, A. H. Goldstein ${ }^{2}$, P. J. Wooldridge ${ }^{1}$, C. Minejima ${ }^{1}$, and R. C. Cohen ${ }^{1,3}$ \\ ${ }^{1}$ Department of Chemistry, University of California, Berkeley, CA, USA \\ ${ }^{2}$ Department of Environmental Science, Policy and Management, University of California, Berkeley, CA, USA \\ ${ }^{3}$ Department of Earth and Planetary Science, University of California, Berkeley, CA, USA \\ *now at: Scripps Institution of Oceanography, University of California, San Diego, La Jolla, USA \\ ** now at: Cooperative Institute for Research in Environmental Science (CIRES), University of Colorado, Boulder, CO, USA
}

Received: 16 December 2008 - Published in Atmos. Chem. Phys. Discuss.: 3 February 2009

Revised: 23 June 2009 - Accepted: 2 July 2009 - Published: 22 July 2009

\begin{abstract}
Observations of $\mathrm{NO}, \mathrm{NO}_{2}$, total peroxy nitrates ( $\Sigma$ PNs), total alkyl nitrates ( $\Sigma \mathrm{ANs}), \mathrm{HNO}_{3}, \mathrm{CO}, \mathrm{O}_{3}$, and meteorological parameters were obtained from October 2000 through February 2002 at $1315 \mathrm{~m}$ a.s.l., $38.9^{\circ} \mathrm{N}, 120.6^{\circ} \mathrm{W}$ on Sierra Pacific Industries land, adjacent to the University of California Blodgett Forest Research Station (UC-BFRS). We describe the data set with emphasis on the diurnal cycles during summertime 2001. We show that transport of the Sacramento urban plume is a primary factor responsible for diurnal variation in total reactive nitrogen mixing ratios as well as in $\mathrm{NO}_{\mathrm{x}}, \Sigma$ PNs and $\Sigma$ ANs, all of which exhibit a late afternoon/early evening peak. In contrast, $\mathrm{HNO}_{3}$ has a peak just after local noon indicating that $\mathrm{HNO}_{3}$ is in near steady state during the day with production due to photochemistry and removal by deposition and mixing with the background free troposphere. Boundary layer dynamics influence mixing ratios of all species in the early morning. Analysis of the morning feature suggests that higher mixing ratios of $\mathrm{NO}_{\mathrm{x}}$ and $\mathrm{HNO}_{3}$ persist in the residual layer than in the nocturnal boundary layer indicating the presence of nocturnal sinks of both species. Nighttime observations also indicate large $\mathrm{HNO}_{3}$ and $\Sigma$ ANs production through oxidation of alkenes by $\mathrm{NO}_{3}$.
\end{abstract}

\section{Introduction}

Tropospheric $\mathrm{NO}_{\mathrm{x}}\left(\equiv \mathrm{NO}+\mathrm{NO}_{2}\right)$ radicals exert strong influences over ozone $\left(\mathrm{O}_{3}\right)$ and organic aerosol production

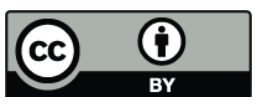

Correspondence to: R. Cohen, (rccohen@berkeley.edu) (e.g. Kroll et al., 2006). Oxidation of $\mathrm{NO}_{\mathrm{x}}$ produces peroxy nitrates $\left(\mathrm{RO}_{2} \mathrm{NO}_{2}, \mathrm{PNs}\right)$, alkyl and multifunctional alkyl nitrates $\left(\mathrm{RONO}_{2}, \mathrm{ANs}\right), \mathrm{HONO}, \mathrm{NO}_{3}, \mathrm{~N}_{2} \mathrm{O}_{5}$ and nitric acid $\left(\mathrm{HNO}_{3}\right)$, all of which are thought to be removed from the atmosphere more rapidly than $\mathrm{NO}_{\mathrm{x}}$. However, rates of removal vary by at least an order of magnitude (Farmer et al., 2006 and references therein) and in some locations these higher oxides are important sources of $\mathrm{NO}_{\mathrm{x}}$ (e.g. Smyth et al., 1996; Singh et al., 1992; Horowitz et al., 2007). Documenting and testing our understanding of the mechanisms affecting atmospheric $\mathrm{NO}_{\mathrm{x}}$ and $\mathrm{NO}_{\mathrm{y}}\left(\mathrm{NO}_{\mathrm{y}} \equiv \mathrm{NO}+\mathrm{NO}_{2}+\Sigma \mathrm{RO}_{2} \mathrm{NO}_{2}+\right.$ $\left.\Sigma \mathrm{RONO}_{2}+\mathrm{HNO}_{3}+\mathrm{HONO}+\mathrm{NO}_{3}+\mathrm{N}_{2} \mathrm{O}_{5}+\ldots\right)$ remains a significant challenge, in large part because of the analytical challenge of measuring all of the key components of $\mathrm{NO}_{\mathrm{y}}$ is one that is still not adequately met. For example, ANs, especially those derived from isoprene, terpenes, and aromatics, are calculated to be important reservoirs of reactive nitrogen, however, only one group has reported field measurements of specific isoprene-derived nitrates (Giacopelli et al., 2005; Grossenbacher et al., 2004; Grossenbacher et al., 2001) and one group has reported field measurements of aromatic nitrates (e.g., Woidich et al., 1999; Schneider et al., 1998). Laboratory studies of isoprene nitrate formation remain controversial with a range of a factor of 3 in the reported yields (Chen et al., 1998; Sprengnether et al., 2002; Tuazon and Atkinson, 1990; Paulot et al., 2008; Chuong and Stevens, 2002; Patchen et al., 2007).

In our own work, we have reported field observations of the sum of all molecules with the chemical formula $\mathrm{RONO}_{2}$ ( $\Sigma$ ANs) and also the sum of all peroxynitrates, molecules of the form $\mathrm{RO}_{2} \mathrm{NO}_{2}$ ( $\Sigma \mathrm{PNs}$ ). The $\Sigma \mathrm{AN}$ measurements have been used to conclude that isoprene nitrate yields are at the

Published by Copernicus Publications on behalf of the European Geosciences Union. 
low end of the range of reported laboratory measurements (Horowitz et al., 2007). Moreover, analysis of these measurements have shown that varying the range of isoprene-nitrate yields (from $4.4 \%$ to $12 \%$ ) results in a constrained range of lifetimes of isoprene nitrates (from $5 \mathrm{~h}$ to $1.5 \mathrm{~h}$ ) within the continental boundary layer (Perring et al., 2008). This analysis also yields coupled values for the recycling efficiency ( $92 \%$ to $74 \%$ ) at which reaction of isoprene nitrates result in another $\mathrm{AN}$ rather than production of $\mathrm{NO}_{\mathrm{x}}$ or $\mathrm{HNO}_{3}$, demonstrating that reaction of isoprene nitrates generally maintains the AN functionality.

Here, we use measurements of the summertime diurnal cycle of $\mathrm{NO}_{y}$ partitioning among the species $\mathrm{NO}, \mathrm{NO}_{2}, \Sigma \mathrm{PNs}$, $\Sigma$ ANs and $\mathrm{HNO}_{3}$ as constraints to evaluate our understanding of the processes affecting partitioning of $\mathrm{NO}_{\mathrm{y}}$ within the continental boundary layer. The measurements were made near the University of California - Blodgett Forest Research Station (UC-BFRS), $5 \mathrm{~h}$ downwind of the edge of the Sacramento urban sprawl. Previous analyses of nitrogen oxide observations from this site have emphasized the importance of $\Sigma$ ANs and their identity as the "missing $\mathrm{NO}_{\mathrm{y}}$ " (Day et al., 2003), day-of-week effects that couple $\mathrm{NO}_{\mathrm{x}}$ to $\mathrm{OH}$ mixing ratios (with consequent observable effects for reactive VOC) Murphy et al., 2007), the effects of temperature on summertime $\mathrm{NO}_{y}$ partitioning (Day et al., 2008), and comparison to upwind (Granite Bay) and downwind (Big Hill) observations (Murphy et al., 2006). Observations of fluxes of $\mathrm{NO}_{\mathrm{yi}}$ have been discussed and analyzed to provide evidence for upward and downward components of vertical exchange indicating that a large source of $\mathrm{OH}$ in the forest canopy exists (Farmer and Cohen, 2008). Here, we examine our understanding of the effects of biogenic emissions, chemistry and transport as they impact the diurnal variation in $\mathrm{NO}_{\mathrm{y}}$ partitioning and $\mathrm{NO}_{\mathrm{yi}}$ mixing ratios. We use these diurnal variations to evaluate our understanding of some of the key chemical and dynamical processes involved in determining production and removal rates of various categories of $\mathrm{NO}_{\mathrm{y}}$.

\section{Experimental}

\subsection{Site description}

Measurements were made from October 2000 to February 2002 on Sierra Pacific Industries (SPI) land near the University of California - Blodgett Forest Research Station (UC-BFRS) (1315 m a.s.1., 38.9 $\left.\mathrm{N}, 120.6^{\circ} \mathrm{W}\right)$ (Fig. 1). The site is a managed ponderosa pine plantation located in the mid Sierra Nevada Mountains $75 \mathrm{~km}$ northeast of Sacramento, CA (pop. 410000 , Greater Sacramento Area $\cong 2$ million) in a sparsely populated region. The climate at this site is discussed in detail in Dillon et al. (2002) and Kurpius et al. (2002). Briefly, the climate of the western Sierras has a wet and a dry season. The dry season (May-September) is characterized by warmer temperatures,

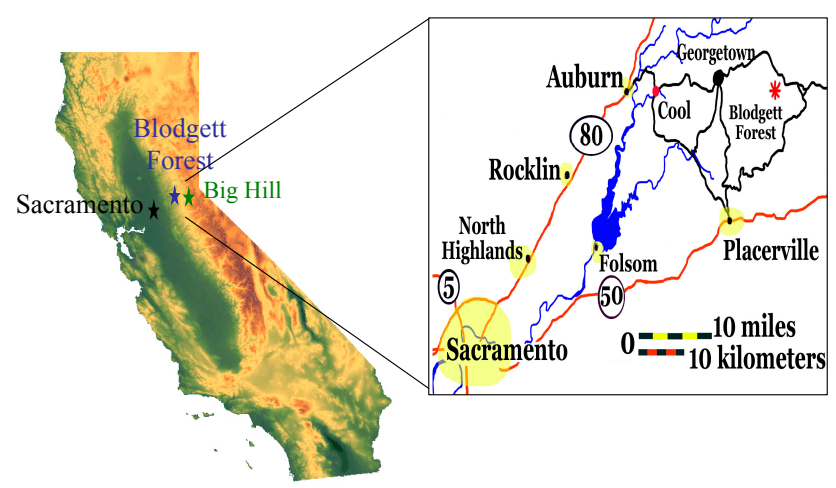

Fig. 1. Relief map of California showing blow-up of Sacramento to Blodgett Forest region.

low rainfall, clear skies, and steady, regular east/west, upslope/downslope winds. The wet season (October-April) is characterized by cooler temperatures, moderate rainfall or snowfall, and less regular wind patterns. Temperatures peak in summer (June-August) and are lowest in late-fall through winter. The annual cycle at UC-BFRS is similar to the climatology in the city of Sacramento reviewed by Dillon et al. (2002) except that it is typically $5-10^{\circ} \mathrm{C}$ colder at the higher elevation of UC-BFRS. During the dry season, upslope winds of $2-3 \mathrm{~m} / \mathrm{s}$ from the southwest are observed during the day, switching at 18-19 (local standard time) to downslope winds of $0.5-2 \mathrm{~m} / \mathrm{s}$ from the northeast with a return to southwesterlies at 7-8. Summer measurements described in this paper span the months of JuneSeptember (2001) and are characterized by almost no precipitation ( $<2 \mathrm{~cm}$ total), consistently warm temperatures (average daily peak $=24^{\circ} \mathrm{C}$ ), and extremely persistent and regular daily wind flow patterns.

A $12 \mathrm{~m}$ walk-up tower was used as a sampling platform and supporting equipment was mounted on the tower or housed in a small wooden shed and a modified refrigerated shipping container. The inlet for the TD-LIF instrument described below was located at 11 meters above ground level (a.g.1., $9 \mathrm{~m}$ before February 2000) and at $\sim 3-5 \mathrm{~m}$ above the forest canopy. For most concentration and flux measurements $\left(\mathrm{NO}_{\mathrm{yi}}, \mathrm{VOC}, \mathrm{O}_{3}, \mathrm{CO}_{2}, \mathrm{H}_{2} \mathrm{O}\right.$, etc. $)$ made prior to 1999, sample air was drawn from $\sim 9 \mathrm{~m}$ a.g.l. or 3-6 $\mathrm{m}$ above the tree canopy (Dillon, 2002; Dreyfus et al., 2002; Goldstein et al., 2000; Goldstein and Schade, 2000; Lamanna and Goldstein, 1999; Schade et al., 1999a) and then beginning in 1999 from 11-12 $\mathrm{m}$ a.g.1. (3-5 $\mathrm{m}$ above canopy) (Bauer et al., 2000; Goldstein and Schade, 2000; Kurpius et al., 2002; Spaulding et al., 2003; Kurpius et al., 2003). During 2004 2005 eddy covariance flux measurements of $\mathrm{NO}_{\mathrm{yi}}$ were conducted at $14.3 \mathrm{~m}$ a.g.1. (7 $\mathrm{m}$ above canopy) (Farmer and Cohen, 2008). The site was powered by a diesel generator located $\sim 130 \mathrm{~m}$ to the northwest. During the day, southwesterlies were strong enough that plumes from the generator were 
rarely observed. At night, the winds were weaker and more variable in direction, and occasional short-duration plumes from the generator were observed.

\subsection{TD-LIF measurements}

Thermal dissociation - laser induced fluorescence (TD-LIF) was used to measure $\mathrm{NO}_{2}$, total peroxy nitrates ( $\left.\Sigma \mathrm{PNs}\right)$, total alkyl nitrates ( $\Sigma$ ANs), and $\mathrm{HNO}_{3}$ at UC-BFRS. The TD-LIF technique is described in detail in Day et al. (2002) and application of the technique to both urban and rural ground sites is described in Day et al. (2003, 2008), Rosen et al. (2004), Cleary et al. (2005, 2007), Murphy et al. (2006) and Farmer et al. $(2006,2008)$ and the free troposphere in Murphy et al. (2004) and Perring et al. (2008). Briefly, for the UCBFRS TD-LIF instrument, an ambient sample flows rapidly through an inlet and is immediately split into four channels. The first one is used to observe $\mathrm{NO}_{2}$; the second is heated to $180^{\circ} \mathrm{C}$ causing thermal dissociation (TD) of $\Sigma$ PNs, the third to $350^{\circ} \mathrm{C}$ for additional TD of $\Sigma$ ANs, and the fourth to $550^{\circ} \mathrm{C}$ to include $\mathrm{TD}$ of $\mathrm{HNO}_{3}$. The temperatures noted are characteristic of the particular oven design, and are proxies for higher temperatures of the gas flowing within the ovens. The dissociation of all of these species produces $\mathrm{NO}_{2}$ with unit efficiency. Differences between the $\mathrm{NO}_{2}$ signals observed simultaneously from channels heated to adjacent temperature set-points are used to derive absolute abundances of each of these four classes. For example, $\Sigma$ PNs are the difference in $\mathrm{NO}_{2}$ detected in the $180^{\circ} \mathrm{C}$ and ambient channels. Both the volatile and semi-volatile components of $\Sigma$ ANs and $\mathrm{HNO}_{3}$ (i.e., $\mathrm{NH}_{4} \mathrm{NO}_{3}$ ) are detected (Bertram and Cohen, 2003; Fountoukis et al., 2007). However, there are no $\mathrm{NH}_{3}$ sources in the vicinity of UC-BFRS. $\mathrm{NH}_{3}$ measurements made at UC-BFRS during the summer of 2006 were too low for $\mathrm{NH}_{4} \mathrm{NO}_{3}$ to exist in equilibrium with the gas phase $\mathrm{NH}_{3}$ and $\mathrm{HNO}_{3}$ present (Fischer and Littlejohn, 2007). We assume $\mathrm{NH}_{3}$ changed little over the last decade at this site. Compounds that decompose into NO such as HONO or organic nitrites are not detected in any of the TD-LIF channels but can be measured with detection of NO (Pérez et al., 2007). A comparison of $\Sigma \mathrm{NO}_{\mathrm{yi}}\left(\Sigma \mathrm{NO}_{\mathrm{yi}} \equiv \mathrm{NO}\right.$ (measured by chemiluminescence) $+\mathrm{NO}_{2}+\Sigma \mathrm{PNs}+\Sigma \mathrm{ANs}+\mathrm{HNO}_{3}$ ) and total $\mathrm{NO}_{\mathrm{y}}$ (measured by catalysis - chemiluminescence) shows that these two values are usually comparable (Day et al., 2003; Dillon, 2002) suggesting that nitrites and non-volatile nitrates are minor at this site.

The inlet (from sample entry through complete dissociation) has a $50-100 \mathrm{~ms}$ residence time. In order to ensure maximum transmission of $\mathrm{HNO}_{3}$ and other "sticky" compounds through the inlet (Neuman et al., 1999; Ryerson et al., 1999), a heating unit $\left(60^{\circ} \mathrm{C}\right)$ was fixed to the PFA tubing upstream of the heated quartz ovens. The inlet consisted of four quartz ovens ( $120 \mathrm{~cm}$ long, $6.4 \mathrm{~mm}$ o.d., $3.8 \mathrm{~mm}$ i.d.) insulated and mounted in steel electrical conduits. Following the quartz ovens, the pressure was reduced 10 -fold by a stainless steel pinhole in order to decrease the residence time and minimize secondary chemistry in the transit via the $20 \mathrm{~m}$ PFA tubing to the detection cells. The flow rate in each channel was approximately 1500-2000 standard cubic centimeters per minute $(\mathrm{sccm})$. The total flow of approximately $45 \mathrm{l} / \mathrm{s}$ at the detection cell pressure of 3 torr was maintained by the combination of a small roots blower (five-fold boost) and an oil-based mechanical pump (91/s).

The TD-LIF instrument is capable of routine, continuous, autonomous, in situ measurements that are accurate $(15 \%)$ and sensitive. Typical detection limits were $90 \mathrm{ppt} / 10 \mathrm{~s}$ $(\mathrm{S} / \mathrm{N}=2)$ on a background of $1 \mathrm{ppb} \mathrm{NO}_{2}$ (total dissociated $\mathrm{NO}_{2}$ in the channel at lower temperature when differencing as in the case of $\Sigma$ ANs and $\mathrm{HNO}_{3}$ ) and $30 \mathrm{ppt} / 10 \mathrm{~s}$ on a background of $100 \mathrm{ppt} \mathrm{NO}_{2}$. The uncertainty in the instrument zero during this experiment was typically $\pm 10 \mathrm{ppt}$. This uncertainty results from photon counting statistics and from drift in the detection cell laser scatter due primarily to temperature-driven laser alignment changes that occurred rapidly compared to measurement of the instrument zero. In the analysis presented in this paper, 30-min averages were used, reducing the detection limits based solely on counting statistics to $7 \mathrm{ppt}$ and $2 \mathrm{ppt}$ for the above cases. For 30min data, the detection limits and precision are probably controlled mostly by the zero uncertainty and the relative accuracy of the calibrations.

The instrument was calibrated every $2.5 \mathrm{~h}$ using an $\mathrm{NO}_{2}$ standard (5.85 ppm in $\mathrm{N}_{2}$, Scott Specialty Gas) diluted to $1-10 \mathrm{ppb}$ in zero air. The calibration mixture was injected (overflow) in the inlet to ensure that the calibration gas mixture passes through a nearly identical flow path to an ambient sample. Zeros were measured approximately every hour, using separate tubing for the pure zero air and the $\mathrm{NO}_{2}$ calibration mixture to ensure the zero determinations were not compromised by residual $\mathrm{NO}_{2}$.

We also introduced a variety of diagnostics to check the accuracy of our calibration and analysis routines. Standard additions of $\mathrm{NO}_{2}$ were performed 2-3 times per day (through the calibration line). The standard additions were used to confirm that corrections in the calibration due to quenching by ambient water (1-9\%) are accurately modeled (Thornton et al., 2000) and to assess the effect of $\mathrm{NO}_{2}$ on retrieved $\Sigma$ PNs, $\Sigma$ ANs, and $\mathrm{HNO}_{3}$ (Rosen et al., 2002, 2004; Day et al., 2002). Also, every three hours, while continuing to sample ambient air, the temperature set-point of one or more ovens was dropped to the adjacent temperature below the normal sampling temperature in order to confirm that the calibrations of the adjacent cells were precise, relative to one another. This also ensured that measurements of the instrument zero in each channel were accurate, with no systematic bias between the adjacent channels observed. Approximately twice each week and always after maintenance of an oven, all three ovens were slowly $\left(20^{\circ} \mathrm{C} / \mathrm{min}\right)$ and simultaneously ramped down from their normal set-points to slightly below the adjacent set-point. This allowed us to determine the tem- 
perature at which each class of compounds begins to dissociate and the temperature required for full dissociation. We never observed a large change in the required set-points and thus kept the set-points constant throughout the experiment.

\subsection{Measurements of $\mathrm{NO}, \mathrm{NO}_{\mathrm{y}}, \mathrm{CO}, \mathrm{O}_{3}$, and Meteorol- ogy}

$\mathrm{NO}$ and $\mathrm{NO}_{\mathrm{y}}$ measurements were made at UC-BFRS using $\mathrm{NO}-\mathrm{O}_{3}$ chemiluminescence (Thermo Environmental Co. model 42CTL). A converter of molybdenum oxide (MoO) mesh, maintained at $325^{\circ} \mathrm{C}$ to convert $\mathrm{NO}_{\mathrm{y}}$ species to $\mathrm{NO}$, was located $40 \mathrm{~cm}$ downstream from the sample intake. The 30-s measurement cycle was split equally between $\mathrm{NO}_{\mathrm{y}}$, NO, and background measurements. Laboratory experiments conducted following the experiment identified a leak resulting in crosstalk between the $\mathrm{NO}_{\mathrm{y}}$ and $\mathrm{NO}$ channels. This, in combination with elevated nighttime NO concentrations $(\sim 20 \mathrm{ppt})$, indicate that the NO measurements may have been affected by a positive bias. Correcting the NO data using results from the laboratory tests and the ambient $\mathrm{NO}$ and $\mathrm{NO}_{\mathrm{y}}$ observations did not produce convincing results. For typical nighttime conditions $\left(60 \mathrm{ppb} \mathrm{O}_{3}, 16^{\circ} \mathrm{C}\right) \mathrm{a}$ sustained NO concentration of $20 \mathrm{ppt}$ would result in production of $>10 \mathrm{ppb} \mathrm{NO} 2$ during an 8-h night. Such a large production rate of $\mathrm{NO}_{2}$ is unrealistic at this location. Therefore, the analysis below uses uncorrected NO data. We estimate that the bias was at most $+20-25$ ppt. Also, where possible, gaps in the NO data set were filled with steady-state estimates from the $\mathrm{NO}_{2}$ and $\mathrm{O}_{3}$ measurements combined with the average diurnal cycle of the steady-state term, $\mathrm{NO} \cdot \mathrm{O}_{3} / \mathrm{NO}_{2}$. The estimated NO concentrations were used only for calculating $\Sigma \mathrm{NO}_{\text {yi }}$ concentrations, and were generally less than $5 \%$.

Wind speed, wind direction, humidity, temperature, $\mathrm{CO}_{2}$ and $\mathrm{O}_{3}$ concentrations, net radiation, photosyntheticallyactive radiation, and pressure were measured as described in Goldstein et al. (2000) and Bauer et al. (2000). CO measurements were obtained using gas chromatographic separation followed by a reduction gas detector (RGD2, Trace Analytical, Incorporated). The instrument was calibrated using a $\mathrm{CO}$ standard diluted to $50-500 \mathrm{ppb}$ in CO-free zero air. VOC were measured as described in Goldstein et al. (2000), Bauer et al. (2000), and Schade et al. (2001).

\subsection{Data processing}

TD-LIF data were collected at 1 or $5 \mathrm{~Hz}$ and averaged to 10 -s means. Nighttime generator spikes produced periods marked by highly elevated (10-200 ppb), variable $\mathrm{NO}_{2}$ values of short duration (10-500s), and high $\mathrm{NO}_{2} / \Sigma \mathrm{NO}_{\mathrm{yi}}$ and $\mathrm{NO} / \Sigma \mathrm{NO}_{\text {yi }}$ ratios. These periods were identified by comparing $10-\mathrm{s}_{2}$ concentrations to a 20 -min running median filter, and all affected TD-LIF (14\% nighttime TD-LIF data), $\mathrm{NO}$ and $\mathrm{CO}$ data were removed prior to averaging and analysis.
Table 1. Number of 30-min points used and percent of coverage for dataset. Data points and percentages shown are for the summer period from 1 June 2001-30 September 2001, and in parentheses, for all data from 3 October 2000-9 February 2002.

\begin{tabular}{lll}
\hline Compound & No. of 30-min Points & $\%$ Coverage \\
& & \\
\hline $\mathrm{NO}$ (chemiluminescence) & $2943(7965)$ & $50.3(25.5)$ \\
$\mathrm{NO}$ (chemi. + estimated) ${ }^{\dagger}$ & $4475(15098)$ & $76.4(48.4)$ \\
$\mathrm{NO}_{2}$ & $3664(11595)$ & $62.6(37.2)$ \\
$\Sigma \mathrm{PNs}$ & $3517(10877)$ & $60.1(34.9)$ \\
$\Sigma \mathrm{ANs}$ & $3564(10936)$ & $60.9(35.1)$ \\
$\mathrm{HNO}_{3}$ & $3635(10608)$ & $62.1(34.0)$ \\
$\mathrm{NO} \mathrm{yi}_{\mathrm{yi}}$ & $3508(10195)$ & $59.9(32.7)$ \\
$\mathrm{O}_{3}$ & $4536(18448)$ & $77.5(59.1)$ \\
\hline
\end{tabular}

$\dagger$ Data acquired directly with chemiluminescence instrument in addition to estimates of $\mathrm{NO}$ based on $\mathrm{NO}_{2}$ and $\mathrm{O}_{3}$ measurements.

Data used in the following analysis are half-hour medians of $\mathrm{NO}_{\mathrm{yi}}$ and $\mathrm{CO}$ data, and means of $\mathrm{O}_{3}$ and meteorological observations. Table 1 shows the number of $30-\mathrm{min}$ data points available for each compound along with the percent coverage from 1 June through 30 September 2001. In addition, 12 cumulative days in late August and early September (all or parts of 19-21, 26-31 August and 7-11 September) were removed from the analysis since large effects from forest fires in the region were clearly identified by abnormally high $\mathrm{CO}$ and $\Sigma \mathrm{NO}_{\text {yi }}$ concentrations.

\subsection{Summertime regional transport, emissions and mi- crometeorology}

The role of transport and anthropogenic emissions in the summertime Sacramento plume, as observed at UC-BFRS, are described by Lamanna and Goldstein (1999) and Dillon et al. (2002). Briefly, the upslope/downslope flow pattern that characterizes transport in the western Sierras imposes a regular pattern on concentrations of chemicals that have their source in the Greater Sacramento Area (Murphy et al., 2006). The concentrations of these compounds increase throughout the day during the upslope flow from the southwest $\left(245^{\circ}\right)$. Downslope flow from the northeast $\left(50^{\circ}\right)$ returns cleaner air to the site with minimum concentrations observed in the early morning. Concentrations of long-lived species (e.g. acetylene) typically begin to increase at noon and reach their peak at $22 \mathrm{~h}$ (10:00 p.m. local standard time), 2-3 h after the shift to downslope flow, suggesting that the center of the plume is slightly to the north of UC-BFRS. Concentrations drop gradually after the $22 \mathrm{~h}$ peak reaching a minimum in mid-morning $(10 \mathrm{~h})$. 
The exceptionally regular wind patterns on the western slopes of the Sierra Nevada with strong daytime upslope flow and weaker nighttime downslope flow make the site particularly useful for studying atmospheric chemistry. The upslope flow that brings air from the direction of Sacramento passes across a band of oaks that are strong isoprene emitters downwind of the city. In the morning air from the west with a weak urban influence but strong influence from the oaks arrives first, followed by air that has both strong oak and urban influences. In the evening the downslope return flow brings that same air back over the site along with cleaner air from the high Sierra and free troposphere.

The daily patterns are controlled by solar insolation and temperature cycling, which in turn affect chemistry, biology and meteorology. Surface warming creates a well-mixed boundary layer below the free troposphere. Shortly after sunset, colder surface temperatures drive a much lower stable nocturnal boundary layer underneath a residual layer and the free troposphere. Stable conditions minimize exchange between these nocturnal layers. In the morning, heating at the surfaces causes this nocturnal boundary layer to break up, mixing down air from the residual layer and forming a convective mixed layer under the free troposphere.

\section{Observations}

Figure 2a shows observations (30-min medians) of $\mathrm{NO}, \mathrm{NO}_{2}$, $\Sigma$ PNs, $\Sigma$ ANs, $\mathrm{HNO}_{3}, \Sigma \mathrm{NO}_{\mathrm{yi}}, \mathrm{CO}, \mathrm{O}_{3}$, temperature, and wind direction during a typical summer period (12-26 July). Skies were clear and no precipitation occurred on these days. The wind patterns were nearly constant, except during the night of 15 July. Overall, the timing of variations in $\mathrm{CO}$, $\mathrm{O}_{3}, \Sigma \mathrm{NO}_{\mathrm{yi}}, \mathrm{NO}_{2}, \Sigma \mathrm{PNs}$, and $\Sigma$ ANs was similar with peaks late in the afternoon followed by decreases until early morning. In contrast, $\mathrm{NO}$ and $\mathrm{HNO}_{3}$ peaked at midday. There is also some variability evident on synoptic time scales. For example, from 12-16 July, temperature, $\mathrm{CO}, \mathrm{O}_{3}, \Sigma \mathrm{NO}_{\mathrm{yi}}, \mathrm{NO}_{2}$, $\Sigma$ PNs, $\mathrm{HNO}_{3}$, and $\Sigma$ ANs, decreased reaching minima on the 15th or 16th. On 17-18 July, temperatures increased, along with most species. Both the nighttime lows and midday peaks roughly followed these trends. 21-24 July shows a similar trend when maximum daily temperatures increased steadily from 20 to $29^{\circ} \mathrm{C}$. Figure $2 \mathrm{~b}$ shows an example of relatively uncommon periods where the winds shifted to the south during nighttime (1, 4 June) and in general is a cooler period for summer. Diurnal cycles in the observed mixing ratios are still apparent although with smaller variation and lower correlation to synoptic variability. In contrast, Fig. 2c shows a period in mid-September when observed mixing ratios have stronger diurnal cycles than typical and with stronger correlations to synoptic-timescale temperature patterns.

Average diurnal patterns of $\mathrm{NO}_{\mathrm{yi}}, \mathrm{CO}, \mathrm{O}_{3}$, meteorological variables and the NO: $\mathrm{NO}_{2}$ ratio are shown in Figs. 3 and 4. The points represent median values and the lines bound the central 68th percentile. Note that NO concentrations shown in Fig. 4 are the measured NO concentrations, whereas $\Sigma \mathrm{NO}_{\mathrm{yi}}$ concentrations in Fig. 3 include both measured and estimated NO concentrations.

\section{Diurnal patterns of individual reactive nitrogen classes}

We observe patterns in the variability of the concentrations on four distinct dynamical timescales: seasonal, synoptic, day-of-week, and diurnal. Seasonal cycles will be the subject of a separate manuscript. Synoptic variability in the summer is, in large part, a temperature effect that is described in Day et al. (2008). Day-of-week patterns and their causes and effects are discussed in Murphy et al. (2006). Here we concentrate on the diurnal variability and restrict our analysis of diurnal patterns to weekday data (Tuesday-Friday). Observations on Saturday, Sunday and Monday display similar patterns in the diurnal cycles of the reactive nitrogen species but at lower overall mixing ratios because of reduced weekend emissions in the region. Also there are some changes in the ratios of species due to $\mathrm{NO}_{\mathrm{x}}$-controlled decreases in $\mathrm{OH}$ on weekends.

\section{1 $\Sigma \mathrm{NO}_{\mathrm{yi}}$}

During summer 2001, $\Sigma \mathrm{NO}_{\mathrm{yi}}$ (Fig. 3) peaked during 15-19h (at $3 \mathrm{ppb}$ ) and, coincident with the change in wind flow, decreased gradually to morning lows (1.6 ppb). CO (Fig. 3) peaked about $2 \mathrm{~h}$ later, decreased more slowly and reached a broad minimum in mid-morning before rising again. These patterns are largely controlled by transport of the Sacramento plume and its mixing with cleaner air from the high Sierra and free troposphere. Once the urban plume has left the region of strong anthropogenic influence the only additional sources of $\mathrm{CO}$ are oxidation of anthropogenic and biogenic VOC and photolytic or temperature-driven emission from plants or soils (Schade et al., 1999b; Schade and Crutzen, 1999 and references therein). Shade et al. (1999b) observed total $\mathrm{CO}$ emission rates from a dry grass savanna of $250 \times 10^{9} \mathrm{~cm}^{-2} \mathrm{~s}^{-1}$ for typical solar irradiance at UC-BFRS during summer mid-afternoon $\left(\sim 800 \mathrm{~W} / \mathrm{m}^{2}\right)$. If this surface flux were mixed into an $800 \mathrm{~m}$ boundary layer, subject to dilution during the 5-h transect from Sacramento to UC-BFRS $\left(0.31 \mathrm{~h}^{-1}\right.$; Pérez and Cohen, 2009), the result would be an additional $1.4 \mathrm{ppb}$ rise observed at UC-BFRS, approximately $7 \%$ compared to the observed $\sim 20 \mathrm{ppb}$ rise for $12-17 \mathrm{~h}$.

The additional $\mathrm{CO}$ added to the plume through oxidation of biogenic VOC can be estimated using methyl vinyl ketone (MVK) and methacrolein (MACR) observations. In the initial oxidation steps of isoprene, the reactions producing these two compounds also produce the co-product, formaldehyde, at a 1:1 ratio (Fuentes et al., 2000 and ref- 

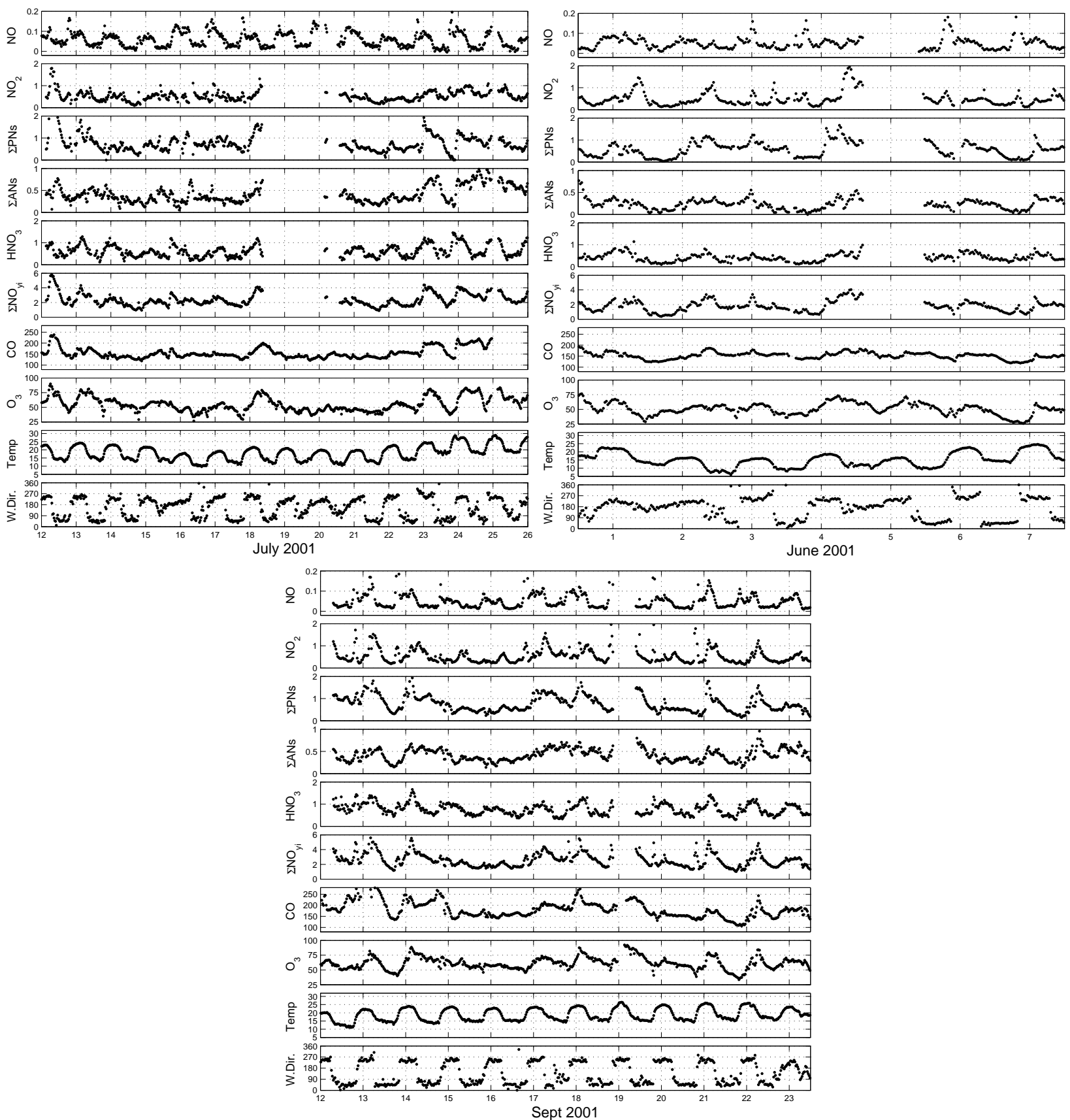

Fig. 2. Observations of $\mathrm{NO}, \mathrm{NO}_{2}, \Sigma \mathrm{PNs}, \Sigma \mathrm{ANs}, \mathrm{HNO}_{3}, \Sigma \mathrm{NO}_{\mathrm{yi}}, \mathrm{CO}, \mathrm{O}_{3}$, temperature $\left({ }^{\circ} \mathrm{C}\right)$, and wind direction for (a) July 2001 , (b) June 2001, and (c) September 2001. Data are 30-min medians except ozone and wind direction which are 30-min means. All concentrations are in ppb.

erences therein). Formaldehyde can be photolyzed or react with $\mathrm{OH}$, always leading to production of one $\mathrm{CO}$ molecule (Fried et al., 1997). Observations during summer 2001, on average, displayed a $0.42 \mathrm{ppb}$ increase in [MVK+MACR] from the morning windshift to $17 \mathrm{~h}$. Correcting for chemical loss of [MVK+MACR] due to reac- tion with $\mathrm{OH}$ in the $\sim 2$-h transit from the primary isoprene source (for $\mathrm{OH}=1 \times 10^{7}$ molecules $\mathrm{cm}^{-3}$ ) yields a total source of $2.4 \mathrm{ppb}$ formaldehyde. The mid-day lifetime of formaldehyde $\left(\mathrm{OH}=1 \times 10^{7}\right.$ molecules $\left.\mathrm{cm}^{-3}\right)$ is approximately $1.5 \mathrm{~h}$ (photolysis rate from (UCAR/NCAR/ACD, 2006) $\mathrm{H}_{2} \mathrm{CO}+\mathrm{OH}$ rate constant from Sander, 2006). There- 

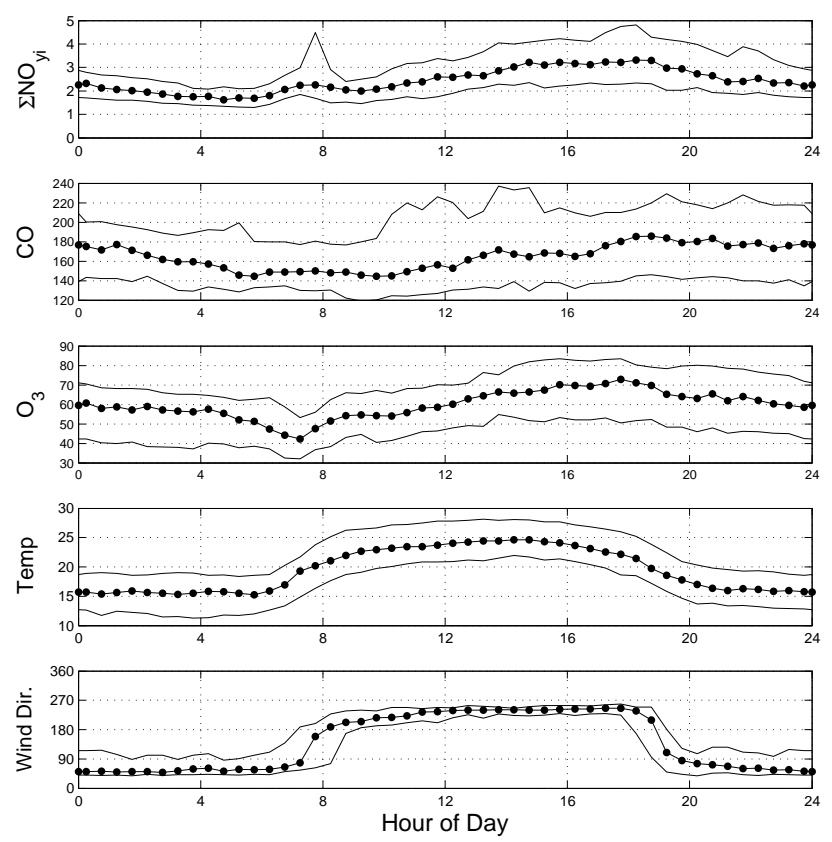

Fig. 3. $\Sigma \mathrm{NO}_{\mathrm{yi}}, \mathrm{CO}, \mathrm{O}_{3}$, temperature $\left({ }^{\circ} \mathrm{C}\right)$ and wind direction for summer 2001 (weekdays only). Data are 30-min medians and lines bound the central 68th percentile. All concentrations are in ppb.

fore, approximately $75 \%$ of the formaldehyde will react, producing $\sim 1.8 \mathrm{ppb} \mathrm{CO}$, or $\sim 9 \%$ of the observed $\mathrm{CO}$ increase. The isoprene oxidation products and $\mathrm{CO}$ will be diluted into different background concentrations as the plume advects from the isoprene source band, however the increases observed at UC-BFRS will be affected proportionally.

Chemical removal of $\mathrm{CO}$ is too slow to be important on a 5-h time scale, thus diurnal variation in $\mathrm{CO}$ mixing ratios are primarily affected by the intensity of transport of the Sacramento urban plume, the magnitude of VOC oxidation, direct natural emissions and the mixing of the plume into the background atmosphere. $\mathrm{NO}_{\mathrm{y}}$ is also affected by these same transport and mixing processes and in addition, natural emissions (from soils) may be a significant source of $\mathrm{NO}_{\mathrm{y}}, 50$ $130 \mathrm{ppt}$ or $7-20 \%$, of the $700 \mathrm{ppt}$ midday increase (for surface emission of 5.8-15 ppt $\mathrm{NO}_{\mathrm{x}} \mathrm{m} \mathrm{s}^{-1}$ (Herman et al., 2003; Farmer and Cohen, 2008), $800 \mathrm{~m}$ boundary layer height, and dilution at $0.31 \mathrm{~h}^{-1}$; including $\mathrm{HNO}_{3}$ production and deposition discussed in Sect. 4.3). Unlike $\mathrm{CO}, \mathrm{NO}_{\mathrm{y}}$ is subject to removal by dry deposition during transport. The occurrence of the peak of $\Sigma \mathrm{NO}_{\mathrm{yi}}$ two hours earlier than peak of $\mathrm{CO}$ is one indicator that, in addition to the transport, emission and deposition processes are important controls over $\mathrm{NO}_{\mathrm{y}}$.

The diurnal pattern in $\mathrm{NO}_{\mathrm{y}}$ at this site is unusual. Urban and rural sites often have diurnal cycles that appear to be primarily controlled by boundary layer height. When the boundary layer is thin, $\mathrm{NO}_{\mathrm{x}}$ sources produce nighttime maxima in $\mathrm{NO}_{\mathrm{y}}$ and much lower $\mathrm{NO}_{\mathrm{y}}$ is observed during the day
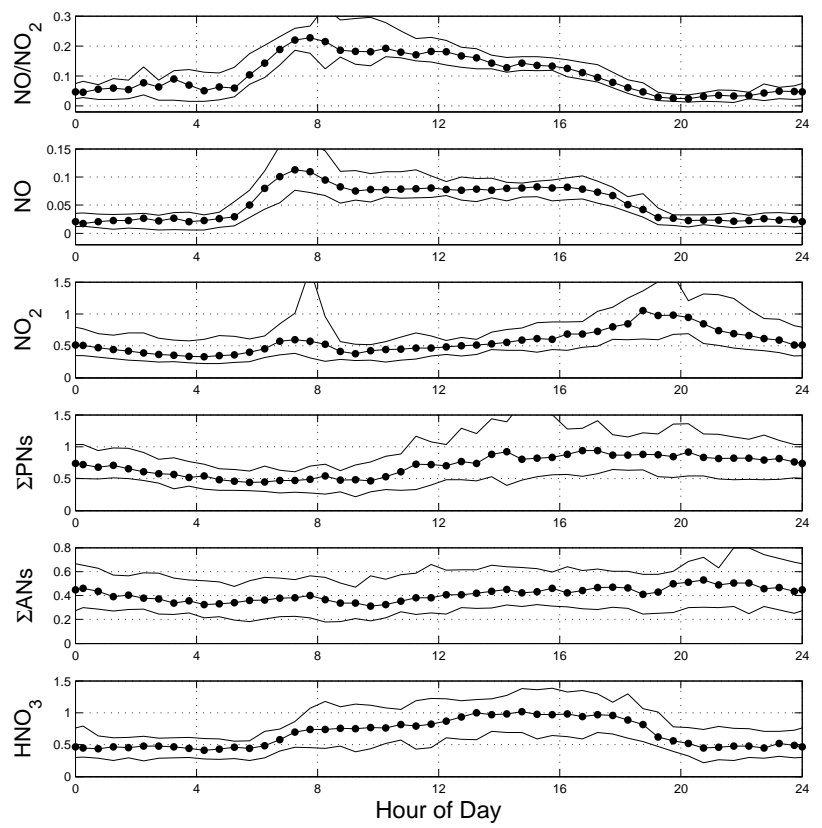

Fig. 4. $\mathrm{NO} / \mathrm{NO}_{2}, \mathrm{NO}, \mathrm{NO}_{2}, \Sigma \mathrm{PNs}, \Sigma \mathrm{ANs}$ and $\mathrm{HNO}_{3}$ for summer 2001 (weekdays only). Data are 30-min medians and lines bound the central 68th percentile. All concentrations are in ppb.

(Buhr et al., 1990; Parrish et al., 1993; Aneja et al., 1996; Munger et al., 1996; Thornton et al., 2002). Mountaintop sites that are isolated above the boundary layer at night exhibit lower $\mathrm{NO}_{\mathrm{y}}$ concentrations at night (Parrish et al., 1993; Zellweger et al., 2000). Although boundary layer height certainly plays an important role affecting the individual classes of $\mathrm{NO}_{\mathrm{yi}}$ at UC-BFRS, the upslope/downslope flow pattern dominates the diurnal cycle in total $\mathrm{NO}_{\mathrm{y}}$ with some modifications to the pattern superimposed through biosphereatmosphere exchange (Farmer and Cohen, 2008).

\section{$4.2 \mathrm{NO}_{\mathrm{x}}$}

The major features in the diurnal cycle of $\mathrm{NO}, \mathrm{NO}_{2}$ and $\mathrm{NO}_{\mathrm{x}}$ are:

\section{1. $17-20 \mathrm{~h} \mathrm{NO}$ x peak}

\section{Daytime $\mathrm{NO} / \mathrm{NO}_{2}$ ratio}

\section{AM peaks}

The primary $\mathrm{NO}_{\mathrm{x}}$ peak occurred between $17-20 \mathrm{~h}$, later than the 15-19h peak of $\Sigma \mathrm{NO}_{\mathrm{yi}}$ (Fig. 4). The $\mathrm{NO}_{\mathrm{x}}$ peak was concurrent with the peak in $\mathrm{CO}$. The match in timing of $\mathrm{CO}$ and $\mathrm{NO}_{\mathrm{x}}$ suggests that the $\mathrm{NO}_{\mathrm{x}}$ is primarily emitted in Metropolitan Sacramento and not downwind. The timing may also be an indicator of slowing photochemistry in the late evening. $\mathrm{CO}$ and $\mathrm{NO}_{\mathrm{y}}$ observations in Sacramento during this same period exhibited a slope of 13.7 molecules $\mathrm{CO}$ 
per molecule $\mathrm{NO}_{\mathrm{y}}$ (Sacramento-Del Paso Manor, ARB Site 34295; http://www.arb.ca.gov/adam). This slope is very similar to the CO: $\mathrm{NO}_{\mathrm{x}}$ emission ratio of 15.4 reported for lightduty vehicles as measured in the Caldecott tunnel in the San Francisco Bay area the same year (Ban-Weiss et al., 2008). In comparison, a plot of the $\mathrm{CO}$ vs. $\mathrm{NO}_{\mathrm{x}}$ concentrations observed at UC-BFRS for the peak period (17-20 h) yields a slope of $50 \mathrm{CO}$ per $\mathrm{NO}_{\mathrm{x}}$. Since nearly all the $\mathrm{NO}_{\mathrm{y}}$ measured in Sacramento is $\mathrm{NO}_{\mathrm{x}}$, and since additional $\mathrm{NO}_{\mathrm{x}}$ and CO sources (discussed in Sect. 4.1) are only of order 10-20\% of the afternoon increase, this indicates that approximately $70 \%$ of the $\mathrm{NO}_{\mathrm{x}}$ (not lost to dilution effects) was oxidized during the transport of the Sacramento plume to UC-BFRS. The corresponding $\mathrm{CO}$ vs. $\mathrm{NO}_{\mathrm{y}}$ slope at UC-BFRS was 22 $\mathrm{CO} / \mathrm{NO}_{\mathrm{y}}$ indicating that of order $40 \%$ of the $\mathrm{NO}_{\mathrm{y}}$ was lost to deposition during plume transport.

$\mathrm{NO}_{\mathrm{x}}$ decreases rapidly, immediately after the 17-20 h peak, with a slower decrease after midnight. In contrast, $\mathrm{CO}$ concentrations decreased smoothly and continuously from $17-21 \mathrm{~h}$ until morning. The more rapid decrease in nighttime $\mathrm{NO}_{\mathrm{x}}$ compared to $\mathrm{CO}$ is due to a combination of mixing with the low- $\mathrm{NO}_{\mathrm{x}}$ background air $(\sim 50 \mathrm{ppt})$ and to chemical conversion of $\mathrm{NO}_{2}$ to $\mathrm{NO}_{3}$ and $\mathrm{N}_{2} \mathrm{O}_{5}$ at night. A calculation including $\mathrm{NO}_{3}$ formation and subsequent $\mathrm{N}_{2} \mathrm{O}_{5}$ formation (in equilibrium with thermal decomposition) for a summer night at UC-BFRS predicts that $\sim 70 \%$ of the $\mathrm{NO}_{\mathrm{x}}$ will be converted to $\mathrm{NO}_{3}+\mathrm{N}_{2} \mathrm{O}_{5}$ during an 8-h night in the NBL. Chemical losses of $\mathrm{NO}_{3}+\mathrm{N}_{2} \mathrm{O}_{5}$ could account for nearly all of the nighttime decrease of $\mathrm{NO}_{\mathrm{x}}$ from $0.9 \mathrm{ppb}$ to $0.35 \mathrm{ppb}$. However, the air transported past this location during nighttime comes from further east. Although air upwind is affected by the urban plume, the degree is likely less and further dilution may have occurred, making it likely that several effects in addition to chemistry are responsible for the nocturnal decrease (see Sect. 5.1 for additional discussion).

NO displayed a broad maximum during daytime ( $\sim 80 \mathrm{ppt})$ and a nearly constant minimum during nighttime (Fig. 4). During the day $\mathrm{NO}$ is produced by photolysis of $\mathrm{NO}_{2}$ and is lost by reaction with ozone and peroxy radicals $\left(\mathrm{RO}_{2}\right.$ and $\left.\mathrm{HO}_{2}\right)$. These photochemical reactions establish a photostationary-state that controls the concentration of $\mathrm{NO}$ relative to $\mathrm{NO}_{2}$. The ratio of NO: $\mathrm{NO}_{2}$ displays a broad midday maximum $(\sim 0.18)$. Differences in the diurnal patterns of $\mathrm{NO}$ and $\mathrm{NO}: \mathrm{NO}_{2}$ are used to elicit information about the local peroxy radical concentrations (see Sect. 5.3).

The secondary maximum in the morning exhibits peaks in $\mathrm{NO}, \mathrm{NO}_{2}$, and the $\mathrm{NO} / \mathrm{NO}_{2}$ ratio. Evidence that these are driven by dynamical mixing of the nocturnal boundary and residual layers is presented in Sect. 5.2.

\section{$4.3 \mathrm{HNO}_{3}$}

Transport of the Sacramento urban plume had less effect on the timing of the diurnal cycle of $\mathrm{HNO}_{3}$ compared to the organic nitrates and $\mathrm{NO}_{\mathrm{x}}$ (Fig. 4). The phase of the diurnal cycle is similar to that of sunlight and to temperature. We suggest that $\mathrm{HNO}_{3}$ at this site is controlled by local production and rapid losses. $\mathrm{HNO}_{3}$ production and losses are modeled as in Eq. (1) assuming chemical production, deposition, and dilution of $\mathrm{HNO}_{3}$ are in steady state (Day et al., 2008):

$k_{\mathrm{OH}+\mathrm{NO}_{2}}[\mathrm{OH}]\left[\mathrm{NO}_{2}\right]=$
$\frac{V_{\mathrm{dep}}}{H_{\mathrm{ml}}}\left[\mathrm{HNO}_{3}\right]+K_{\mathrm{dil}}\left(\left[\mathrm{HNO}_{3}\right]-\left[\mathrm{HNO}_{3}\right]_{\mathrm{bg}}\right)$

Here $V_{\text {dep }}$ is the deposition velocity $(0.034 \mathrm{~m} / \mathrm{s}$; Farmer and Cohen, 2008), $H_{\mathrm{ml}}$ is the mixed layer height $(\sim 800 \mathrm{~m}$; Carroll and Dixon, 1998; Dillon et al., 2002; Seaman et al., 1995), $K_{\text {dil }}$ is the dilution rate constant representing both vertical venting and horizontal diffusion of the plume into the background air $\left(0.31 \mathrm{~h}^{-1}\right.$; Pérez and Cohen, 2009), and $\left[\mathrm{HNO}_{3}\right]_{b g}$ is the background nitric acid concentration into which the plume is diluted. We estimate that the freetropospheric $\left[\mathrm{HNO}_{3}\right]_{\mathrm{bg}}$ for this region is $200 \mathrm{ppt}$ which is the intercept of $\left[\mathrm{HNO}_{3}\right]$ vs. $\left[\mathrm{H}_{2} \mathrm{O}\right]$ for similar observations discussed in Murphy et al. (2006) made at a site at higher elevation in the Sierras where the sampling site was often affected by free tropospheric air.

Calculations using Eq. (1) predict daytime $\mathrm{HNO}_{3}$ concentrations have a shape similar to that of $\mathrm{OH}$ and to the variation in solar insolation (e.g. Brown et al., 2004). The observed diurnal cycles are consistent with this prediction.

At night, when $\mathrm{OH}$ concentrations are much lower, the $\mathrm{OH}$ source term approaches zero and $\mathrm{HNO}_{3}$ concentrations should be controlled by deposition and decrease to a small fraction of daytime values. However, the $\mathrm{HNO}_{3}$ decreased less than expected and remained relatively constant at night. This observation suggests local $\mathrm{HNO}_{3}$ production through $\mathrm{NO}_{3}$ and $\mathrm{N}_{2} \mathrm{O}_{5}$ formation and subsequent reactions and/or continued downward mixing of residual layer air are occurring at night. However, downward mixing of air would likely bring PNs with it, which would be inconsistent with observations of decreasing $\Sigma$ PNs throughout the night at UC-BFRS. Nighttime $\mathrm{N}_{2} \mathrm{O}_{5}$-driven $\mathrm{HNO}_{3}$ production has been invoked to explain substantial fluxes of $\mathrm{NO}_{\mathrm{y}}$ at night (Munger et al., 1996; Munger et al., 1998) and observations of elevated $\mathrm{HNO}_{3}$ and depressed $\mathrm{N}_{2} \mathrm{O}_{5}$ at night (Brown et al., 2004). Our observations are consistent with the presence of an additional source of $\mathrm{HNO}_{3}$ as discussed in more detail in Sect. 5.1.

For summertime mid-day concentrations of $0.5 \mathrm{ppb} \mathrm{NO}_{2}$ and $1 \mathrm{ppb} \mathrm{HNO}_{3}$ (and average boundary layer temperatures and gas density based on a mid-day surface temperature of $24^{\circ} \mathrm{C}$ ) we use Eq. (1) to calculate an $\mathrm{OH}$ concentration of $2.1 \times 10^{7}$ molecules $\mathrm{cm}^{-3}$, approximately double that of the integrated value in the Sacramento plume of $1.1 \times 10^{7}$ molecules $\mathrm{cm}^{-3}$ calculated by Dillon et al. (2002). The lifetime of $\mathrm{HNO}_{3}$ to the combination of deposition and dilution is $\sim 2.2 \mathrm{~h}$. Therefore, much of the $\mathrm{HNO}_{3}$ observed 


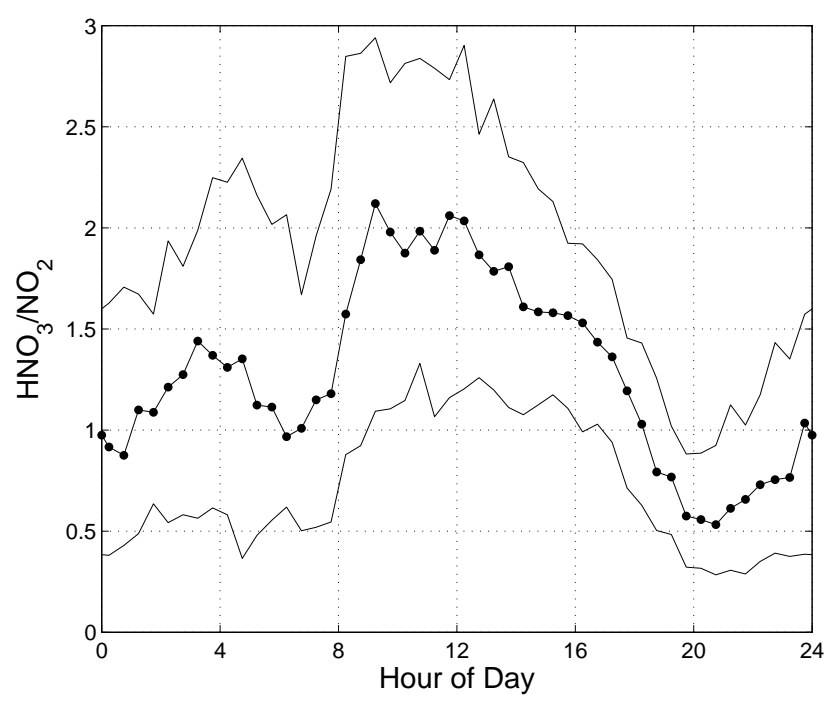

Fig. 5. $\mathrm{HNO}_{3} / \mathrm{NO}_{2}$ for summer 2001 (weekdays only). Data are 30 -min medians and lines bound the central 68th percentile.

at UC-BFRS may be produced upwind. Moreover, concentrations of $\mathrm{NO}_{\mathrm{x}}$ and $\mathrm{OH}$ two hours upwind are two to three times higher than observed at UC-BFRS, respectively (Murphy et al., 2007), suggesting that $\mathrm{HNO}_{3}$ production may be occurring much more rapidly upwind. Consequently, these factors imply that not only is the $\mathrm{OH}$ calculated using Eq. (1) probably more representative of the integrated $\mathrm{OH}$ a few hours upwind, but furthermore is biased high due to the underestimate of $\mathrm{NO}_{2}$ concentrations that are relevant to conditions where the $\mathrm{HNO}_{3}$ was produced. This factor likely explains the high $\mathrm{OH}$ estimate compared to that of Dillon et al. (2002). Detailed time dependent model calculations support this idea and suggest an average $\mathrm{OH}$ of $5.0 \times 10^{6}$ molecules $\mathrm{cm}^{-3}$ (Pérez and Cohen, 2009).

The rapid decrease of $\mathrm{HNO}_{3}$ at sunset $(18-21 \mathrm{~h})$ is consistent with a short lifetime $(\sim 2.2 \mathrm{~h})$, however, it might be expected that when the $\mathrm{OH}$ value drops significantly (likely shortly after solar noon), the $\mathrm{HNO}_{3}$ concentration would decrease on this timescale. As observed in Fig. 4, a rapid decrease does not occur until hour 18. The ratio $\mathrm{HNO}_{3} / \mathrm{NO}_{2}$, shown in Fig. 5, does peak at solar noon and displays a rapid decrease starting after hour 16. This indicates the lag in $\mathrm{HNO}_{3}$ concentrations is due to increased $\mathrm{NO}_{2}$ and no unusual chemistry.

Another interesting feature in the diurnal cycle of $\mathrm{HNO}_{3}$ is the absolute minimum and local minimum in $\mathrm{HNO}_{3} / \mathrm{NO}_{2}$ near sunrise and sunset (Fig. 5), the transition period between daytime and nighttime chemistry. Brown et al. (2004) observed similar features in their observations of $\mathrm{HNO}_{3}$ which they attribute to the dusk/dawn transition period when there is insufficient sunlight to drive significant production of $\mathrm{OH}$ but sufficient sunlight to produce enough $\mathrm{NO}$ from $\mathrm{NO}_{2}$ photolysis to suppress $\mathrm{NO}_{3}$ concentrations.
The diurnal cycle of $\mathrm{HNO}_{3}$ at UC-BFRS is similar to observations at other sites and indicates that transport is less important as a control over $\mathrm{HNO}_{3}$ than for $\mathrm{CO}$ and other $\mathrm{NO}_{\mathrm{y}}$ species at the site. Lefer et al. (1999) report a similar diurnal cycle for summertime measurements of $\mathrm{HNO}_{3}$ at Harvard Forest, where median values reached 2 ppb at midday and dropped to $400-700 \mathrm{ppt}$ at night for the more polluted wind sector. For the cleaner wind sector, a much smaller amplitude cycle was observed (150 ppt at night, 300 ppt during daytime). Horii (2002) reported similar diurnal cycles for another summer at Harvard Forest although the amplitude for the polluted sector data was less than reported by Lefer et al. (1999). For a mountain site, Niwot Ridge, Colorado, Parrish et al. (1986) show a similar diurnal cycle that, on average, peaked around $350 \mathrm{ppt}$ and dropped to $\sim 80 \mathrm{ppt}$ at night during the summer. They also report that, on average, $\mathrm{HNO}_{3}$ concentrations and both the observed and modeled $\mathrm{HNO}_{3} / \mathrm{NO}_{\mathrm{x}}$ ratio peaked a few hours after noon. Kleinman et al. (1994) show $\mathrm{HNO}_{3}$ observations from a site in rural Georgia with a very similar diurnal cycle to our summer data with nighttime values of $\sim 300 \mathrm{ppt}$ and a daytime peak of $\sim 1 \mathrm{ppb}$. Brown et al. (2004) describe $\mathrm{HNO}_{3}$ measurements for the relatively polluted marine boundary layer off the eastern US coast and observe that $\mathrm{HNO}_{3}$ peaks near midday at nearly $2 \mathrm{ppb}$ and persists at $0.5-1 \mathrm{ppb}$ during nighttime.

\section{$4.4 \quad \Sigma$ PNs}

$\Sigma$ PNs are approximately in thermal equilibrium with peroxyacyl radicals $\left(\mathrm{PA}_{i}\right)$ and $\mathrm{NO}_{2}$ under warm boundary layer conditions:

$\mathrm{K}_{\mathrm{PN}_{\mathrm{i}}}(\mathrm{T})=\frac{\left[\mathrm{PN}_{\mathrm{i}}\right]}{\left[\mathrm{PA}_{\mathrm{i}}\right]\left[\mathrm{NO}_{2}\right]}$

where $\mathrm{K}_{\mathrm{PNi}}(\mathrm{T})$ is the equilibrium constant for each respective PN. This equilibrium is established through the reactions:

$\mathrm{PA}_{\mathrm{i}}+\mathrm{NO}_{2} \rightarrow \mathrm{PN}_{\mathrm{i}}$

$\mathrm{PN}_{\mathrm{i}} \rightarrow \mathrm{PA}_{\mathrm{i}}+\mathrm{NO}_{2}$

which determine the partitioning of the $\mathrm{PN}$ reservoir between the stable $\mathrm{PN}_{\mathrm{i}}$ and its radical partner, $\mathrm{PA}_{\mathrm{i}}$. In addition, peroxyacyl radicals are also approximately in photochemical steady-state with their sources and sinks (Cleary et al., 2007; LaFranchi et al., 2009).

The primary reactions that contribute to net formation and loss of the sum of a $\mathrm{PA}_{\mathrm{i}}$ and $\mathrm{PN}_{\mathrm{i}}\left(\mathrm{PN}_{T i} \equiv \mathrm{PA}_{i}+\mathrm{PN}_{\mathrm{i}}\right)$ include:

aldehyde $_{\mathrm{i}}$, ketone $_{\mathrm{i}}+\mathrm{OH}\left(+\mathrm{O}_{2}\right) \rightarrow \mathrm{PA}_{\mathrm{i}}+\mathrm{H}_{2} \mathrm{O}$

$\mathrm{PA}_{\mathrm{i}}+\mathrm{NO} \rightarrow$ Products

$\mathrm{PA}_{\mathrm{i}}+\mathrm{HO}_{2} \rightarrow$ Products

$\mathrm{PA}_{\mathrm{i}}+\mathrm{RO}_{2} \rightarrow$ Products 
$\mathrm{PN}_{\mathrm{i}}+\mathrm{OH} \rightarrow$ Products

Since Reaction (7) will have a small effect for most PN molecules, we neglect it and solve for the steady-state concentration of $\mathrm{PN}_{T i}$ and derive:

$\left[\mathrm{PN}_{\mathrm{T}_{\mathrm{i}}}\right]_{\mathrm{ss}}=$

$\frac{k_{3}\left[\text { aldehyde }_{\mathrm{i}}\right][\mathrm{OH}]}{k_{4}[\mathrm{NO}]+k_{5}\left[\mathrm{HO}_{2}\right]+k_{6}\left[\mathrm{RO}_{2}\right]}\left(1+\mathrm{K}_{\mathrm{PN}_{i}}\left[\mathrm{NO}_{2}\right]\right)$

This relationship is similar to that derived by Cleary et al. (2007) with the addition of peroxy radical reactions which are important sinks of PA radicals at UC-BFRS but were not in the region studied by Cleary et al. (2007). At UC-BFRS, noontime $\mathrm{NO}$ was observed to be $80 \mathrm{ppt}$ and the $\left[\mathrm{HO}_{2}+\mathrm{RO}_{2}\right]$ was calculated to be $\sim 160 \mathrm{ppt}$ (Sect. 4.4). If we approximate that $\mathrm{RO}_{2}$ is equal to $\mathrm{HO}_{2}$ and use the reaction rate constant of $\mathrm{CH}_{3} \mathrm{C}(\mathrm{O}) \mathrm{O}_{2}+\mathrm{CH}_{3} \mathrm{O}_{2}$ for Reaction (6), the net contribution of Reactions (5) and (6) to $\mathrm{PA}_{i}$ destruction is calculated to be 1.3 times that of Reactions (4).

At UC-BFRS, $\Sigma$ PNs peaked at $17 \mathrm{~h}$ in the afternoon and decreased continuously through the night until about $6-10 \mathrm{~h}$, at which point they began to increase (Fig. 4). The rapid rise in $\Sigma$ PNs of $50 \%$ in late morning (from 0.5 to $0.75 \mathrm{ppb}$ @ 9-11 h) is concurrent with a comparable $45 \%$ increase in acetaldehyde from 0.43 to $0.62 \mathrm{ppb}$ (data not shown). If the majority of $\Sigma$ PNs consisted of peroxyacetyl nitrate (PAN) and acetaldehyde constituted the principal source of PAN then, according to Eq. (3), the increase in acetaldehyde could explain the morning rise in $\Sigma$ PNs. However, as shown in Eq. (3), several other factors control the PNs concentrations in this steady-state approximation. During this morning rise, $\left[\mathrm{HO}_{2}+\mathrm{RO}_{2}\right]$ and temperature increase, both acting as negative forcing on $\Sigma$ PNs concentrations, whereas $\mathrm{NO}_{2}, \mathrm{OH}$, and acetaldehyde increase, all of which would work to increase $\Sigma$ PNs. The combined effect of these shifts, in addition to changes in the other aldehyde molecules that are precursors to $\mathrm{PA}_{i}$ radicals, account for the observed $\Sigma \mathrm{PNs}$ mid-day profile.

Using average noontime concentrations and temperatures (Figs. 3, 4), approximating that PAN comprises $80 \%$ of $\Sigma$ PNs (Cleary et al., 2007) and that acetaldehyde is the sole source of PAN, we use Eq. (3) to calculate that the noontime $\mathrm{OH}$ concentration is $1.5 \times 10^{7}$ molecules $\mathrm{cm}^{-3}$. This is very similar to the $2.1 \times 10^{7}$ molecules $\mathrm{cm}^{-3}$ calculated in Sect. 4.3 using the photo-stationary state approximation for $\mathrm{HNO}_{3}$ and $\mathrm{NO}_{2}$. However, as discussed, that calculation may substantially overestimate local $\mathrm{OH}$ concentrations in part because it reflects the integrated $\mathrm{OH}$ concentrations between UC-BFRS and a couple hours upwind where $\mathrm{OH}$ concentrations are likely higher by a factor of 2-3.

It has been suggested that in regions heavily influenced by isoprene oxidation that an additional source of peroxyacetyl radicals, as much as 3-fold that of acetaldehyde, are necessary to explain observed PAN levels (Cleary et al., 2007; Roberts et al., 2001). Methylglyoxal (MGLY) has been suggested as a possible identity of this additional source (Romero et al., 2005). If we invoke additional sources of PAN that are 3 times larger than the acetaldehyde source and repeat the calculation using Eq. (3) (see preceding paragraph), we calculate a 4 -fold lower $\mathrm{OH}$ $\left(3.8 \times 10^{6}\right.$ molecules $\left.\mathrm{cm}^{-3}\right)$. The rapid rise in $\Sigma \mathrm{PNs}$ in late morning is concurrent with the timing of morning increases in isoprene, methyl vinyl ketone (MVK), and methacrolein (MACR) (data not shown, see Dreyfus et al. (2002) for similar summertime diurnal cycles at this location). This is consistent with isoprene oxidation accounting for an additional source of PAN in the region. In a recent study, using a more complete suite of VOC observations and three speciated acyl peroxy nitrate compounds at UC-BFRS, LaFranchi et al. (2008) calculate that non-acetaldehyde sources (MGLY, MACR, MVK, and biacetyl) account for $\sim 3$ times that from acetyaldyde for the production of PAN for average midday temperatures observed in this study $\left(24^{\circ} \mathrm{C}\right)$. MVK represented the majority of those other sources and they demonstrated a closure of the peroxy acetyl (PA) radical budget. These additional acyl peroxy radical production sources are all proportional to $\mathrm{OH}$ concentrations (except biacetyl which was $<10 \%$ of PA production), confirming that $\mathrm{OH}$ of approximately $4 \times 10^{6}$ molecules $/ \mathrm{cm}^{3}$ is a more accurate estimate for local noontime $\mathrm{OH}$ concentrations than the higher estimates based on acetaldehyde alone.

The initial component of the evening decrease in $\Sigma$ PNs coincides with decreases in isoprene, MVK, and MACR (but not acetaldehyde). $\Sigma$ PNs continue to decrease gradually throughout the night to $50 \%$ of their mixing ratio at $6 \mathrm{~h}$. We estimate a lower bound on the nighttime chemical loss rate in the absence of $\mathrm{NO}$ by assuming PA radicals are formed through $\Sigma \mathrm{PN}$ decomposition (R2) and that $\mathrm{PA}_{i}-\mathrm{PA}_{i}$ self reactions are the only important sink. For typical nighttime $\Sigma$ PNs (0.7 ppb), $\mathrm{NO}_{2}(0.5 \mathrm{ppb})$, temperature $\left(16^{\circ} \mathrm{C}\right)$, and assuming a pseudo steady-state established by R1 and R2, we estimate approximately $0.6 \mathrm{ppt} \Sigma \mathrm{PA}_{i}$. Self-reaction of $\mathrm{PA}_{i}$ radicals at this concentration would result in a $1 \%$ loss of $\Sigma$ PNs over an 8 -h night. The $\sim 40 \%$ decrease we observe from 20 to $4 \mathrm{~h}$ would be consistent with $\left[\mathrm{RO}_{2}+\mathrm{HO}_{2}\right]$ levels $\sim 20$ times higher $(10 \mathrm{ppt})$ and would result in a $\mathrm{NO}_{\mathrm{x}}$ source of $\sim 200$ ppt. However, nighttime peroxy radical concentrations are probably not this high since losses of $\Sigma$ PNs are also due to reaction with soil NO emissions and surface deposition (see Sect. 5.1).

\section{5 $\Sigma$ ANs}

$\Sigma$ ANs peaked at $20 \mathrm{~h}$ along with other chemicals transported in the Sacramento plume and were lowest in the morning (minima at 5 and $10 \mathrm{~h}$ ) (Fig. 4). 
$\Sigma$ ANs are formed through the minor channel of the reaction of organic peroxy radicals with NO:

$\mathrm{RO}_{2}+\mathrm{NO} \rightarrow \mathrm{RO}+\mathrm{NO}_{2}$

$\mathrm{RO}_{2}+\mathrm{NO} \rightarrow \mathrm{RONO}_{2}$

Reaction (8a) typically leads to the formation of 2 ozone molecules, whereas Reaction (8b) results in formation of an alkyl nitrate. Depending on the R-group the branching ratio can range from one percent to tens of percent. The effective branching ratio for the mixture of VOC present at UCBFRS (Day et al., 2003) and Granite Bay, CA ( 4 h upwind) (Cleary et al., 2005) has been inferred from the $\Sigma$ ANs correlation with $\mathrm{O}_{3}$ to be $\sim 2.5 \%$ and $\sim 4 \%$, respectively.

Losses of $\Sigma$ ANs within the boundary layer can occur though both dry deposition and through reaction with $\mathrm{OH}$. The deposition velocity for $\Sigma$ ANs was calculated to be $0.027 \mathrm{~m} / \mathrm{s}$ during summer, nearly $80 \%$ that of $\mathrm{HNO}_{3}$ (Farmer and Cohen, 2008). This suggests that the stickier hydroxyalkyl nitrates make up a significant fraction of $\Sigma$ ANs. For a daytime boundary layer of $800 \mathrm{~m}$ this corresponds to a lifetime to deposition of $\sim 8 \mathrm{~h}$. The most important chemical reaction for ANs during the day, reaction with $\mathrm{OH}$, can result in products that retain the organic nitrate functionality (R9a) or that convert the nitrogen either to $\mathrm{HNO}_{3}$ or $\mathrm{NO}_{2}$ (see Perring et al. (2008) for additional discussion):

$\mathrm{RONO}_{2}+\mathrm{OH} \rightarrow \mathrm{H}_{2} \mathrm{O}+\mathrm{R}^{\prime} \mathrm{ONO}_{2}$

$\mathrm{RONO}_{2}+\mathrm{OH} \rightarrow \mathrm{HNO}_{3}+\mathrm{R}^{\prime} \mathrm{O}$

$\mathrm{RONO}_{2}+\mathrm{OH} \rightarrow \mathrm{NO}_{2}+\mathrm{RO}(\mathrm{OH})$

Farmer et al. (2008) estimate the $\Sigma$ AN loss branches (R9b and R9c) comprise 6-30\% of the net rate of Reaction (9). For $\mathrm{OH}$ of $5 \times 10^{6}$ molecule $\mathrm{cm}^{-3}$ and a rate constant for Reaction (9) of $4.5 \times 10^{-11}$ molecules $\mathrm{cm}^{-3} \mathrm{~s}^{-1}$ (Horowitz et al., 2007), this corresponds to a lifetime of $4-20 \mathrm{~h}$ for reactive nitrogen in the form of $\Sigma$ ANs (but not necessarily as the original molecular structure). This is a chemical lifetime comparable to the deposition lifetime.

A variety of diurnal behaviors have been reported for $\Sigma$ ANs. Buhr et al. (1990) report measurements of $C_{2}-C_{5}$ mono-functional alkyl nitrates and observed that $\Sigma$ ANs increased in the morning with the nocturnal boundary layer break-up (concurrent with $\mathrm{NO}_{\mathrm{y}}$ increases), remained relatively constant throughout the day, followed by a slow decline at night within the nocturnal boundary layer. Flocke et al. (1998) report measurements of more than 20 different $\mathrm{C}_{1}-\mathrm{C}_{8}$ mono-functional alkyl nitrates for Schauinsland, Germany. During summer, total alkyl nitrates approximately doubled between 9 and $14 \mathrm{~h}$, concurrently with upslope flow from a polluted urban region and increases of $\mathrm{NO}_{\mathrm{y}}$ and $\mathrm{O}_{3}$, and then decreased from evening to the morning. O'Brien et al. (1995) report four days of observations during August at a site in rural Ontario where they measured twelve $\mathrm{C}_{3}-$ $\mathrm{C}_{6}$ mono-functional alkyl nitrates, four $\mathrm{C}_{2}-\mathrm{C}_{4}$ hydroxyalkyl nitrates, and one alkyl di-nitrate. No diurnal cycle was apparent in total or hydroxy- alkyl nitrates. In contrast, O'Brien et al. (1997) describe a month-long experiment where a similar suite of alkyl nitrates was measured $50 \mathrm{~km}$ from Vancouver, B.C. and show that total, total mono-functional-, and total hydroxy- alkyl nitrates (and an unidentified alkyl nitrate component) had a large diurnal cycle peaking in early afternoon. Peak daytime values were 5-10 times the nighttime minima. They suggest that that the bulk of alkyl nitrates were locally produced and that isoprene nitrates may be an important component of alkyl nitrates at this site. At the PROPHET site, Grossenbacher et al. (2001) report measurements of isoprene nitrates that showed a clear diurnal cycle peaking in early afternoon around $10 \mathrm{ppt}$ and decreasing to a 1-2 ppt at night. For the same period at this site, $\mathrm{C}_{3}-$ $\mathrm{C}_{5}$ mono-functional alkyl nitrates were measured and did not display any consistent diurnal cycle (Ostling et al., 2001). In another experiment, in rural Tennessee (Southern Oxidants Study 1999), isoprene nitrates were observed to have a similar diurnal cycle but at 5-10 times the concentrations with an average mid-day peak of $115 \mathrm{ppt}$ (5-10 ppt nighttime minimum) (Grossenbacher et al., 2004). Our own summer measurements at Granite Bay, California and La Porte, Texas exhibited diurnal cycles that varied by a factor of two or four (respectively) between day and night, suggesting that sources were local. The diurnal cycle of $\Sigma$ ANs at UC-BFRS most closely follows that described by Flocke et al. (1998) where daily flow patterns had a stronger influence than local photochemistry.

The diurnal cycle of $\Sigma$ ANs can be contrasted to $\Sigma$ PNs, which peaked earlier and by a greater factor over the morning mixing ratios lows. The observation that $\Sigma$ ANs peaked later during the day than $\Sigma$ PNs suggests that the isoprene-related source, originating in the foothills, is a bigger fraction of the $\Sigma P N$ sources than it is for the $\Sigma A N$ sources. During the nighttime through late-morning $\Sigma$ PNs and $\Sigma$ ANs display a similar pattern, decreasing by a similar relative magnitude with a small increase in mid-morning. There is much greater variability in $\Sigma$ PNs during afternoon (as illustrated by the 68th percentile bounds in Fig. 4). This is due to synoptic timescale temperature effects that affect PNs more strongly than ANs (Day et al., 2008).

To understand the implications of the different relative magnitudes of the diurnal patterns, we compare the various production and loss processes that affect these two compound classes during the daytime. We estimate that the freetropospheric backgrounds of $\Sigma$ PNs and $\Sigma$ ANs for this region are $<50-100 \mathrm{ppt}$, calculated from the intercept of the respective compound class vs. $\left[\mathrm{H}_{2} \mathrm{O}\right]$ for similar observations higher in the Sierras discussed in Murphy et al. (2006). Since both $\Sigma$ ANs and $\Sigma$ PNs do not decrease below $350-400$ ppt during their morning minima, much higher than their background values, subtle differences in their backgrounds can- 
not explain significant differences in their diurnal patterns. However, the deposition velocity for $\Sigma$ ANs has been shown to be 2.5 times greater than for $\Sigma$ PNs at this site. Therefore, differing deposition rates may partly explain the larger relative increase that $\Sigma$ PNs experience during midday, as deposition of $\Sigma$ ANs acts to depress concentrations. Increases in $\mathrm{OH}$ will also act as a larger direct positive forcing on $\Sigma$ PNs concentrations since although the production of both are roughly proportional to $\mathrm{OH}$, $\Sigma$ ANs have significant $\mathrm{OH}-$ mediated losses (R9b and R9c).

Qualitatively we observe that the period where transport and production result in a net increase of observed $\Sigma$ PNs occurs over a shorter time period (10-17 h) than for $\Sigma$ ANs (10-21 h). After $17 \mathrm{~h}, \Sigma$ PNs decrease. Likely, net chemical production of both $\Sigma$ PNs and $\Sigma$ ANs is slowing at this time of day. However if $\Sigma$ ANs and its precursor VOCs have a larger contribution from within the Sacramento urban plume compared to $\Sigma$ PNs, the increasing impact of the plume during this period $(17-20 \mathrm{~h})$ could drive the gradual increase in $\Sigma$ ANs observed. In effect, this explanation characterizes the $\Sigma$ PNs production as being more concentrated in a smaller band of the plume (due to the line source of BVOC emissions between UC-BFRS and Sacramento) whereas $\Sigma$ ANs sources are distributed more evenly throughout the plume (due to a mixture of biogenic and anthropogenic VOC sources). Also, a broad range of mono and sesqui-terpenes are known to be emitted from the plants at this site (Bouvier-Brown et al., 2009) and their oxidation likely leads to terpene nitrates. This more local source of $\Sigma$ ANs is also consistent with a more temporally diffuse source during the daytime, possibly transitioning into nighttime $\Sigma$ ANs production through reactions with $\mathrm{NO}_{3}$.

\section{Combined analyses}

\subsection{Nocturnal chemistry}

Combining the constraints from our observations of NO, $\mathrm{NO}_{2}, \Sigma \mathrm{PNs}, \Sigma \mathrm{ANs}, \mathrm{HNO}_{3}$, and $\mathrm{O}_{3}$ provides additional insight into nocturnal chemistry. As described above, invoking $\mathrm{NO}_{3}$ and $\mathrm{N}_{2} \mathrm{O}_{5}$ chemistry is necessary to describing the nighttime $\mathrm{NO}_{\mathrm{x}}$ decrease. Minejima (2008) calculated that during the summer at UC-BFRS, $1-10 \%$ of the losses of the sum: $\left[\mathrm{N}_{2} \mathrm{O}_{5}+\mathrm{NO}_{3}\right]$ is due to heterogeneous losses of $\mathrm{N}_{2} \mathrm{O}_{5}$ to aerosol. For that calculation, they use measured $\left[\mathrm{N}_{2} \mathrm{O}_{5}+\mathrm{NO}_{3}\right]$ concentrations of 4 ppt $\left(\mathrm{NO}_{3} / \mathrm{N}_{2} \mathrm{O}_{5}\right.$ of $\left.1: 1\right)$, an upper limit of total aerosol surface area of $600 \mu \mathrm{m}^{2} \mathrm{~cm}^{-3}$ (Lunden et al., 2004), an uptake coefficient of 0.0016 and typical biogenic VOC concentrations observed at UC-BFRS (see references below).

Reactions of $\mathrm{NO}_{3}$ with biogenic VOC (BVOC) and aldehydes:

$\mathrm{NO}_{3}+\mathrm{RH}_{2} \mathrm{RH}_{2} \rightarrow$ Products $\left(\mathrm{RONO}_{2}, \mathrm{NO}_{\mathrm{x}}, \mathrm{HNO}_{3} \ldots\right)$
$\mathrm{NO}_{3}+\mathrm{RH} \rightarrow \mathrm{HNO}_{3}$

are rapid (Bloss et al., 2005; Atkinson and Arey, 2003) and are an estimated $90 \%$ of the combined loss of $\mathrm{NO}_{3}+\mathrm{N}_{2} \mathrm{O}_{5}$. These reactions are a source of the sustained nighttime $\mathrm{HNO}_{3}$ concentrations and also a source of ANs.

As a first step toward a quantitative description of the nocturnal reactive nitrogen chemistry at UC-BFRS, we applied a chemical box model to calculate the temporal evolution of $\mathrm{O}_{3}, \mathrm{NO}_{2}, \mathrm{NO}_{3}, \mathrm{~N}_{2} \mathrm{O}_{5}, \Sigma \mathrm{PNs}, \Sigma \mathrm{ANs}$, and $\mathrm{HNO}_{3}$ at night for typical conditions at UC-BFRS and upwind. The model included 21 important nighttime $\mathrm{NO}_{\mathrm{x}}$ and $\mathrm{HO}_{\mathrm{x}}$ reactions in addition to VOC reactions that were limited to isoprene, $\alpha$ pinene, $\beta$-pinene, and 3-carene reactions with $\mathrm{OH}, \mathrm{O}_{3}$, and $\mathrm{NO}_{3}$ and reactions of aldehydes (as one chemical group) with $\mathrm{OH}$ and $\mathrm{NO}_{3}$.

The model was initialized with observations from Big Hill, CA at 09:00 p.m. (Murphy et al., 2006). Big Hill is $20 \mathrm{~km}$ $(\sim 8 \mathrm{~h}$ at nighttime wind speeds) upwind of UC-BFRS. We then compare the model to observations at 05:00 a.m from UC-BFRS (Figs. 3 and 4). Initial concentrations of $\mathrm{O}_{3}$, $\mathrm{NO}_{2}, \Sigma$ ANs, $\Sigma$ PNs, $\mathrm{HNO}_{3}$ were $61,0.41,0.50,0.49$, and $0.51 \mathrm{ppb}$, respectively (see Murphy et al. (2006), Figs. 13 and 14).

The nocturnal boundary layer was assumed to be $100 \mathrm{~m}$ deep. The aldehyde and BVOC concentrations at Big Hill were estimated to be $70 \%$ of concentrations observed or calculated at UC-BFRS (Lamanna and Goldstein, 1999; Schade et al., 1999a; Holzinger et al., 2006; Lee et al., 2005; Pérez, 2008), an approximation based on dilution of the plume during upslope flow $\left(\sim 0.3 \mathrm{~h}^{-1}\right)$ and smaller upwind BVOC emissions due to less vegetation and lower temperatures. Deposition rates were estimated by assuming that no dilution occurs as the air is transported from Big Hill to UC-BFRS and the decrease in $\mathrm{O}_{3}$ is due solely to deposition. This resulted in a deposition velocity of $\sim 5 \%$ that of daytime values $(\sim 0.6 \mathrm{~cm} / \mathrm{s}$, Bauer et al., 2000), a realistic drop for low turbulence nighttime conditions (Farmer and Cohen, 2008; Finkelstein et al., 2000). Daytime deposition velocities of $\Sigma$ ANs, $\Sigma$ PNs and $\mathrm{HNO}_{3}(2.7,1.1,3.4 \mathrm{~cm} / \mathrm{s})$, reported by Farmer and Cohen (2008) were scaled by this same factor. This resulted in lifetimes to deposition of 21,51 , and $16 \mathrm{~h}$ or corresponding decreases of $32 \%, 15 \%$, and $39 \%$ in an 8-h night, respectively, in the absence of other sources and sinks.

Reactions of $\mathrm{NO}_{3}$ with aldehydes were assumed to produce $\mathrm{HNO}_{3}$ with a $95 \%$ yield and $\mathrm{NO}_{2}$ with a $5 \%$ yield. The overall contribution to $\mathrm{HNO}_{3}$ production via aldehyde reactions was small. However, reaction of $\mathrm{NO}_{3}$ with BVOC [at UC-BFRS: alpha-pinene (140 ppt), beta-pinene (200 ppt), 3carene $(80 \mathrm{ppt})$, isoprene $(600 \mathrm{ppt})]$, had strong control over $\mathrm{NO}_{\mathrm{x}}, \mathrm{HNO}_{3}$, and $\Sigma$ ANs. The relative yields of $\mathrm{HNO}_{3}$, $\Sigma$ ANs, and $\mathrm{NO}_{2}$ was tuned along with soil $\mathrm{NO}_{\mathrm{x}}$ emissions (to compensate for deposition losses) to exactly match $\mathrm{NO}_{2}, \mathrm{HNO}_{3}$, and $\Sigma$ ANs concentrations at UC-BFRS at 05:00 a.m. This resulted in an estimate for the branching ra- 
tio of $\mathrm{BVOC}+\mathrm{NO}_{3}$ of $45 \% \mathrm{HNO}_{3}, 25 \% \mathrm{ANs}$, and the remainder $\mathrm{NO}_{2}$. Soil emissions of $\mathrm{NO}_{\mathrm{x}}$ were $1.3 \mathrm{ppt} \mathrm{m} \mathrm{s}^{-1}$, approximately $10 \%$ that of the daytime emissions calculated by Farmer and Cohen (2008).

The $25 \%$ yield of $\Sigma$ ANs is not to be interpreted as the effect of a primary reaction, but rather as the effective yield over 8 hours. Some $\Sigma$ ANs may react quickly and be returned to the pool of other $\mathrm{N}$ species. We did not attempt to represent these details in this simple model. Clearly, a better representation of the nighttime reactive nitrogen chemistry will require an improved understanding of the branching ratio of $\mathrm{BVOC}+\mathrm{NO}_{3}$ reactions.

\subsection{Morning chemistry and boundary layer dynamics}

At approximately 6 in the morning, at or just before both sunrise and the downslope/upslope windshift, the concentrations of some species were observed to increase rapidly. This is earlier than can be explained by horizontal transport. The timing of these changes coincides with the timing of a rapid decrease in $\mathrm{O}_{3}$ mixing ratios, which has been attributed to a morning stomatal opening in response to sunlight that causes rapid $\mathrm{O}_{3}$ deposition in the shallow nocturnal boundary layer (Kurpius et al., 2002; Bauer et al., 2000).

Rather than a stomatal process, the $\mathrm{NO}_{\mathrm{yi}}$ changes are likely the result of boundary layer dynamics. The $\mathrm{NO}_{\mathrm{x}}$ rise is likely the result of the break-up of the nocturnal boundary layer, mixing down air from the residual layer that is less depleted in $\mathrm{NO}_{\mathrm{x}}$ having experienced less surface deposition and exposed to lower VOC concentrations and therefore less loss through $\mathrm{NO}_{3}$ and $\mathrm{N}_{2} \mathrm{O}_{5}$ reactions. Further, even slight heating at the surface would cause convection of nighttime soil $\mathrm{NO}$ emissions and contribute to increased $\mathrm{NO}_{\mathrm{x}}$. Stomatal NO emissions have been observed from coniferous trees (Wildt et al., 1997) but are unlikely to be large enough to cause the observed mixing ratio trend. More likely, the larger relative rise in $\mathrm{NO}$ as compared to the $\mathrm{NO}_{2}$ is due to the $\mathrm{O}_{3}$ decrease (see Sect. 5.3). Similar observations of $\mathrm{NO}_{\mathrm{x}}$ and a presumed connection to break-up of the nocturnal inversion have been reported for measurements at Scotia, PA (Buhr et al., 1990), Harvard Forest (Munger et al., 1996), and Northern Michigan (Thornberry et al., 2001).

$\mathrm{HNO}_{3}$ typically increased rapidly in the morning starting around hours 6-7, and then was constant or dipped for a few hours before continuing to increase through early afternoon (Figs. 2 and 4). This sharp morning rise preceded the expected rise in $\mathrm{OH}$ concentrations and was coincident with the early morning peaks in $\mathrm{NO}, \mathrm{NO}_{2}$, and $\Sigma$ PNs and with the dip or recovery of $\mathrm{O}_{3}$ from its morning minimum. This feature is similar to observations at other sites during summer. Lefer et al. (1999), Kleinman et al. (1994), and Trainer et al. (1991) point out that the sharp rise in diurnal observations of $\mathrm{HNO}_{3}$ occurs earlier in the morning than they would expect based on the expected $\mathrm{OH}$ profile, but is consistent with the breakup of the nocturnal boundary layer and mixing of higher $\mathrm{HNO}_{3}$ concentrations from above.

A slight peak in both $\Sigma$ ANs and $\Sigma$ PNs also occurs in the morning, concurrent or slightly after the $\mathrm{NO}_{\mathrm{x}}$ peak and is consistent with the nocturnal boundary layer breakup and mixing down of air less depleted in organic nitrates. Although this feature in $\Sigma$ PNs is not reported for other sites possessing a morning $\mathrm{NO}_{x}$ peak or early $\mathrm{HNO}_{3}$ rise, many authors (Roberts et al., 1995; Aneja et al., 1996; Shepson et al., 1992; Thornberry et al., 2001; Bottenheim et al., 1994) have attributed the early morning rise in PAN to breakup of the nocturnal boundary layer with subsequent increases due to photochemical production obscuring an early morning peak as is observed for $\mathrm{NO}_{\mathrm{x}}$. A similar peak was sometimes observed for $\mathrm{CO}$ which may be the result of more rapid soil emissions of $\mathrm{CO}$ following a nighttime build-up initiated by rising temperatures or increased sunlight photolyzing aldehydes that accumulated overnight.

\subsection{Peroxy radicals}

NO concentrations are approximately in steady state with $\mathrm{NO}_{2}$ during daylight. The ratio of $\mathrm{NO} / \mathrm{NO}_{2}$ is inversely proportional to $\mathrm{O}_{3}$ and to the $\mathrm{NO}+\mathrm{O}_{3}$ rate constant and proportional to the $\mathrm{NO}_{2}$ photolysis rate constant. In the absence of local $\mathrm{NO}_{\mathrm{x}}$ emissions or peroxy radicals $\left(\mathrm{HO}_{2}, \mathrm{RO}_{2}\right)$, the relationship between $\mathrm{NO}$ and $\mathrm{NO}_{2}$ is governed by the following reactions:

$\mathrm{NO}_{2}+\mathrm{h} v \rightarrow \mathrm{NO}+\mathrm{O}$
$\mathrm{NO}+\mathrm{O}_{3} \rightarrow \mathrm{NO}_{2}+\mathrm{O}_{2}$

Under these conditions, the photostationary-state approximation yields:

$[\mathrm{NO}] /\left[\mathrm{NO}_{2}\right]=\frac{\mathrm{j}_{12}}{\mathrm{k}_{13}\left[\mathrm{O}_{3}\right]}$

Although peroxy radicals may often be only 10's of ppt in rural locations they react rapidly with $\mathrm{NO}$ (the rate constant is 100 times faster than for the $\mathrm{NO}+\mathrm{O}_{3}$ reaction) converting it to $\mathrm{NO}_{2}$ :

$\mathrm{HO}_{2}+\mathrm{NO} \rightarrow \mathrm{NO}_{2}+\mathrm{OH}$
$\mathrm{RO}_{2}+\mathrm{NO} \rightarrow \mathrm{NO}_{2}+\mathrm{RO}$

This additional conversion of $\mathrm{NO}$ to $\mathrm{NO}_{2}$ is commonly represented as a deviation from photostationary state (as governed solely by R12 and R13) with the equation:

$\phi=\frac{j_{12}\left[\mathrm{NO}_{2}\right]}{\left[\mathrm{O}_{3}\right] k_{13}[\mathrm{NO}]}$

In the absence of $\mathrm{NO}_{\mathrm{x}}$ sources (such that steady-state is achieved), $\phi$ is unity at $\left[\mathrm{HO}_{2}+\mathrm{RO}_{2}\right]=0 . \phi$ increases with increasing $\left[\mathrm{HO}_{2}+\mathrm{RO}_{2}\right]$. In effect phi is the ratio of the stationary state perturbed by peroxy radicals to that unperturbed by 
peroxy radicals. In Fig. 6, the calculated diurnal cycle of $\phi$ is shown. By midday $\phi$ is $2-3$, suggesting the presence of large peroxy radical concentrations and indicating that peroxy radicals are more important to conversion of $\mathrm{NO}$ to $\mathrm{NO}_{2}$ than is reaction with $\mathrm{O}_{3}$. Including $\mathrm{R} 14$ and $\mathrm{R} 8 \mathrm{a}$ in the photostationary-state model yields an equation with which to estimate $\left[\mathrm{HO}_{2}+\mathrm{RO}_{2}\right]$ concentrations:

$\left[\mathrm{HO}_{2}+\mathrm{RO}_{2}\right]=\frac{1}{k_{14}}\left(j_{12} \frac{\left[\mathrm{NO}_{2}\right]}{[\mathrm{NO}]}-k_{13}\left[\mathrm{O}_{3}\right]\right)$

where $k_{14}$ is used for the rate constant of both Reactions (14) and Reactions (8a) since the rate constants are similar. Values for $\mathrm{j}_{12}$ were calculated using the NCAR TUV Radiation Model (UCAR/NCAR/ACD) and scaled to onsite measurements of photosynthetically-active radiation. The average diurnal cycle of $\left[\mathrm{HO}_{2}+\mathrm{RO}_{2}\right]$, derived from Eq. (6), is shown in the bottom panel of Fig. 6. Peroxy radical concentrations were calculated for instantaneous half-hour averages and black lines shown in the figure represent the averages and variability for those calculations. Also shown (dotted grey lines) are average diurnal cycles of $\left[\mathrm{HO}_{2}+\mathrm{RO}_{2}\right]$ calculated using $\pm 30 \%$ of the calculated $\mathrm{j}_{12}$ values. (note: Modeled midday $\left[\mathrm{HO}_{2}+\mathrm{RO}_{2}\right]$ values using lower $\mathrm{NO}$ concentrations corrected by the nighttime non-zero values from a possible leak (see Sect. 2.3) yields $\left[\mathrm{HO}_{2}+\mathrm{RO}_{2}\right]$ values of nearly double that shown in Fig. 6. Therefore, if anything, the uncertainty in NO is responsible for an underestimation of peroxy radical concentrations).

The concentrations of $\left[\mathrm{HO}_{2}+\mathrm{RO}_{2}\right]$ reach $200 \mathrm{ppt}$. These values are 2-8 times higher than other measurements or modeled values at rural, urban, and remote sites where they have typically been reported to have midday peaks of 25100 ppt (Thornton et al., 2002; Mihele and Hastie, 2003; Hauglustaine et al., 1996; Cantrell et al., 1996a, b, 1997). Such high peroxy radical concentrations suggest significant local oxidation of VOCs, either by $\mathrm{OH}$ or $\mathrm{O}_{3}$. For observed mid-afternoon $\mathrm{NO}_{x}$ and $\mathrm{O}_{3}$ concentrations, a VOC reactivity of $8 \mathrm{~s}^{-1}[\mathrm{OH}],[\mathrm{OH}]=5 \times 10^{6}$ molecules $\mathrm{cm}^{-3}$, and using a photostationary state model, we calculate $\mathrm{RO}_{2} \sim$ $\mathrm{HO}_{2} \sim 100$ ppt (see Farmer and Cohen (2008) for details on model). This is consistent with the high $\left[\mathrm{RO}_{2}+\mathrm{HO}_{2}\right]$ we calculate from a $\mathrm{NO}-\mathrm{NO}_{2}-\mathrm{O}_{3}$ photostationary state model and compared to other observations, is attributable to the combination of relatively low $\mathrm{NO}_{\mathrm{x}}$ and high VOC reactivity conditions. A doubling of $\mathrm{OH}$ yields a calculated $50 \%$ increase in $\left[\mathrm{RO}_{2}+\mathrm{HO}_{2}\right]$, therefore an average mid-day $\mathrm{OH}$ concentration of $5 \times 10^{6}$ molecules $\mathrm{cm}^{-3}$ is most consistent with the observed $\mathrm{NO}_{\mathrm{x}}-\mathrm{HO}_{\mathrm{x}}$ chemistry. This comparison provides further evidence that the $\mathrm{NO}_{\mathrm{x}}-\mathrm{HO}_{\mathrm{x}}$ chemistry described here is consistent when viewed from several different perspectives.

\section{Conclusions}

We describe diurnal cycles in summertime observations of $\Sigma \mathrm{NO}_{\text {yi }}, \mathrm{NO}_{2}, \mathrm{NO}, \Sigma \mathrm{PNs}, \Sigma \mathrm{ANs}$, and $\mathrm{HNO}_{3}$ at a forested,
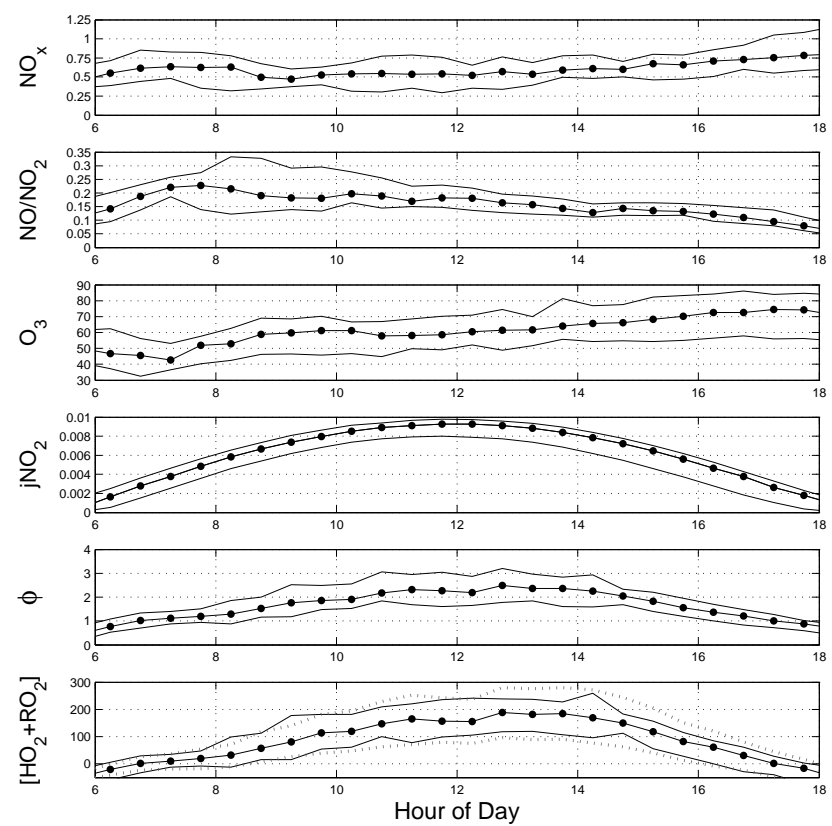

Fig. 6. $\mathrm{NO}_{\mathrm{x}}, \mathrm{NO} / \mathrm{NO}_{2}, \mathrm{O}_{3}, \phi$, and modeled $\left[\mathrm{HO}_{2}+\mathrm{RO}_{2}\right]$ during daytime for summer 2001 (weekdays only). Averages are from only when measurements of $\mathrm{NO}, \mathrm{NO}_{2}$, and $\mathrm{O}_{3}$ where all available. Data are 30-min medians and solid lines bound the central 68th percentile. Dotted grey lines in the bottom panel indicate the average diurnal cycles of $\left[\mathrm{HO}_{2}+\mathrm{RO}_{2}\right]$ calculated using values for $\mathrm{j}_{12}$ of $\pm 30 \%$ the calculated values. All concentrations are in ppb except $\left[\mathrm{HO}_{2}+\mathrm{RO}_{2}\right]$ is ppt.

mid-elevation site in the Sierras affected daily by the Sacramento urban plume. The shifts in the timing and relative amplitudes of the diurnal cycles of different $\mathrm{NO}_{\mathrm{yi}}$ species and the partitioning of $\mathrm{NO}_{\mathrm{z}}$ are attributed to various differences in photochemical production rates, lifetimes, and direct and precursor emission source locations. The diurnal cycle of $\mathrm{HNO}_{3}$ was primarily driven by local photochemistry. The diurnal cycles of $\Sigma$ PNs and $\Sigma$ ANs were largely driven by production and transport within the Sacramento plume, with strong indications that, by comparison, the former has a larger contribution of biogenic VOC precursors.

Daytime peroxy radical concentrations were calculated to be larger than most previous observations, providing evidence for highly oxidizing conditions and favorable conditions for large alkyl nitrate production. Nighttime concentrations of different nitrogen species are driven by a combination of deposition and chemistry, with strong evidence for large nighttime $\mathrm{HNO}_{3}$ and $\Sigma$ ANs production via $\mathrm{NO}_{3}$ +alkenes.

Acknowledgements. We gratefully acknowledge the NSF for funding this research under NSF grant ATM-0138669 and ATM0639847. The authors would like to thank Sierra Pacific Industries for the use of their land and the University of California, Berkeley, Center for Forestry, Blodgett Forest Research Station for coop- 
eration in facilitating this research. Megan McKay and Gunnar Shade from UC Berkeley played a central role in the collection of the $\mathrm{CO}$, VOC and meteorological measurements. We also thank Gunnar Shade for his valuable comments on the interpretation of $\mathrm{CO}$ observations in this manuscript.

Edited by: A. B. Guenther

\section{References}

Aneja, V. P., Kim, D. S., Das, M., and Hartsell, B. E.: Measurements and analysis of reactive nitrogen species in the rural troposphere of Southeast United States: Southern oxidant study site SONIA, Atmos. Environ., 30, 649-659, 1996.

Atkinson, R., and Arey, J.: Gas-phase tropospheric chemistry of biogenic volatile organic compounds: a review, Atmos. Environ., 37, S197-S219, doi:10.1016/s1352-2310(03)00391-1, 2003.

Ban-Weiss, G. A., McLaughlin, J. P., Harley, R. A., Lunden, M. M., Kirchstetter, T. W., Kean, A. J., Strawa, A. W., Stevenson, E. D., and Kendall, G. R.: Long-term changes in emissions of nitrogen oxides and particulate matter from on-road gasoline and diesel vehicles, Atmos. Environ., 42, 220-232, doi:10.1016/j.atmosenv.2007.09.049, 2008.

Bauer, M. R., Hultman, N. E., Panek, J. A., and Goldstein, A. H.: Ozone deposition to a ponderosa pine plantation in the Sierra Nevada Mountains (CA): a comparison of two different climatic years, J. Geophys. Res.-Atmos., 105, 22123-22136, 2000.

Bertram, T. H. and Cohen, R. C.: A prototype instrument for the real time detection of semi-volatile organic and inorganic nitrate aerosol, Eos Trans. AGU, 84(46), Fall Meet. Suppl., San Francisco, USA, 8-12 December 2003, A51F-0740, 2003.

Bloss, C., Wagner, V., Jenkin, M. E., Volkamer, R., Bloss, W. J., Lee, J. D., Heard, D. E., Wirtz, K., Martin-Reviejo, M., Rea, G., Wenger, J. C., and Pilling, M. J.: Development of a detailed chemical mechanism (MCMv3.1) for the atmospheric oxidation of aromatic hydrocarbons, Atmos. Chem. Phys., 5, 641-664, 2005, http://www.atmos-chem-phys.net/5/641/2005/.

Bottenheim, J. W., Sirois, A., Brice, K. A., and Gallant, A. J.: Five years of continuous observations of PAN and ozone at a rural location in eastern Canada, J. Geophys. Res.-Atmos., 99, 53335352, 1994.

Bouvier-Brown, N. C., Holzinger, R., Palitzsch, K., and Goldstein, A. H.: Large emissions of sesquiterpenes and methyl chavicol quantified from branch enclosure measurements, Atmos. Environ., 43, 389-401, doi:10.1016/j.atmosenv.2008.08.039, 2009.

Brown, S. S., Dibb, J. E., Stark, H., Aldener, M., Vozella, M., Whitlow, S., Williams, E. J., Lerner, B. M., Jakoubek, R., Middlebrook, A. M., DeGouw, J. A., Warneke, C., Goldan, P. D., Kuster, W. C., Angevine, W. M., Sueper, D. T., Quinn, P. K., Bates, T. S., Meagher, J. F., Fehsenfeld, F. C., and Ravishankara, A. R.: Nighttime removal of $\mathrm{NO}_{\mathrm{x}}$ in the summer marine boundary layer, Geophys. Res. Lett., 31, L07108, doi:10.1029/2004GL019412, 2004.

Buhr, M. P., Parrish, D. D., Norton, R. B., Fehsenfeld, F. C., Sievers, R. E., and Roberts, J. M.: Contribution of organic nitrates to the total reactive nitrogen budget at a rural eastern U.S. site, J. Geophys. Res.-Atmos., 95, 9809-9816, 1990.

Cantrell, C. A., Shetter, R. E., and Calvert, J.: Peroxy radical chemistry during FIELDVOC 1993 in Brittany, France, Atmos. Envi- ron., 30, 3947-3957, 1996a.

Cantrell, C. A., Shetter, R. E., Gilpin, T. M., Calvert, J. G., Eisele, F. L., and Tanner, D. J.: Peroxy radical concentrations measured and calculated from trace gas measurements in the Mauna Loa observatory photochemistry experiment 2, J. Geophys. Res.Atmos., 101, 14653-14664, 1996b.

Cantrell, C. A., Shetter, R. E., Calvert, J. G., Eisele, F. L., Williams, E., Baumann, K., Brune, W. H., Stevens, P. S., and Mather, J. H.: Peroxy radicals from photostationary state deviations and steady state calculations during the Tropospheric $\mathrm{OH}$ Photochemistry Experiment at Idaho Hill, Colorado, 1993, J. Geophys. Res.Atmos., 102, 6369-6378, 1997.

Carroll, J. J. and Dixon, A. J.: Tracking the Sacramento pollutant plume over the western Sierra Nevada, Contract \#94-334 Final Report, California Environmental Protection Agency Air Resources Board, 26 pp., available online at: http://www.arb.ca. gov/research/apr/past/atmospheric.htm, 1998.

Chen, X. H., Hulbert, D., and Shepson, P. B.: Measurement of the organic nitrate yield from $\mathrm{OH}$ reaction with isoprene, J. Geophys. Res.-Atmos., 103, 25563-25568, 1998.

Chuong, B. and Stevens, P. S.: Measurements of the kinetics of the OH-initiated oxidation of isoprene, J. Geophys. Res.-Atmos., 107, 4162, doi:10.1029/2001jd000865, ISSN: 0148-0227, 2002.

Cleary, P. A., Murphy, J. G., Wooldridge, P. J., Day, D. A., Millet, D., McKay, M., Goldstein, A. H., and Cohen, R. C.: Observations of total alkyl nitrates within the Sacramento Urban Plume, Atmos. Chem. Phys. Discuss., 5, 4801-4843, 2005, http://www.atmos-chem-phys-discuss.net/5/4801/2005/.

Cleary, P. A., Wooldridge, P. J., Millet, D. B., McKay, M., Goldstein, A. H., and Cohen, R. C.: Observations of total peroxy nitrates and aldehydes: measurement interpretation and inference of OH radical concentrations, Atmos. Chem. Phys., 7, 19471960, 2007, http://www.atmos-chem-phys.net/7/1947/2007/.

Day, D. A., Wooldridge, P. J., Dillon, M. B., Thornton, J. A., and Cohen, R. C.: A thermal dissociation laser-induced fluorescence instrument for in situ detection of $\mathrm{NO}_{2}$, peroxy nitrates, alkyl nitrates, and $\mathrm{HNO}_{3}$, J. Geophys. Res.-Atmos., 107, 4046, doi:10.1029/2001JD000779, 2002.

Day, D. A., Dillon, M. B., Wooldridge, P. J., Thornton, J. A., Rosen, R. S., Wood, E. C., and Cohen, R. C.: On alkyl nitrates, $\mathrm{O}_{3}$, and the "missing $\mathrm{NO}_{\mathrm{y}}$ ", J. Geophys. Res.-Atmos., 108, 4501, doi:10.1029/2003JD003685, 2003.

Day, D. A., Wooldridge, P. J., and Cohen, R. C.: Observations of the effects of temperature on atmospheric $\mathrm{HNO}_{3}, \Sigma \mathrm{ANs}, \Sigma \mathrm{PNs}$, and $\mathrm{NO}_{\mathrm{X}}$ : evidence for a temperature-dependent $\mathrm{HO}_{\mathrm{x}}$ source, Atmos. Chem. Phys. Discuss., 8, 1867-1879, 2008, http://www.atmos-chem-phys-discuss.net/8/1867/2008/.

Dillon, M. B.: The chemical evolution of the Sacramento urban plume, Ph. D. thesis, Department of Chemistry, University of California, Berkeley, 206 pp., 2002.

Dillon, M. B., Lamanna, M. S., Schade, G. W., Goldstein, A. H., and Cohen, R. C.: Chemical evolution of the Sacramento urban plume: Transport and oxidation, J. Geophys. Res.-Atmos., 107, 4045, doi:10.1029/2001JD000969, 2002.

Dreyfus, G. B., Schade, G. W., and Goldstein, A. H.: Observational constraints on the contribution of isoprene oxidation to ozone production on the western slope of the Sierra Nevada, CA, J. Geophys. Res.-Atmos., 107, 4365, doi:10.1029/2001JD001490, 2002. 
Farmer, D. K., Wooldridge, P. J., and Cohen, R. C.: Application of thermal-dissociation laser induced fluorescence (TD-LIF) to measurement of $\mathrm{HNO}_{3}, \Sigma$ alkyl nitrates, $\Sigma$ peroxy nitrates, and $\mathrm{NO}_{2}$ fluxes using eddy covariance, Atmos. Chem. Phys., 6, 3471-3486, 2006,

http://www.atmos-chem-phys.net/6/3471/2006/.

Farmer, D. K. and Cohen, R. C.: Observations of $\mathrm{HNO}_{3}, \Sigma \mathrm{AN}$ an $\Sigma \mathrm{PN}$ and $\mathrm{NO}_{2}$ fluxes: Evidence for rapid $\mathrm{HO}_{\mathrm{x}}$ chemistry within a pine forest canopy, Atmos. Chem. Phys., 8, 3899-3917, 2008, http://www.atmos-chem-phys.net/8/3899/2008/.

Finkelstein, P. L., Ellestad, T. G., Clarke, J. F., Meyers, T. P., Schwede, D. B., Hebert, E. O., and Neal, J. A.: Ozone and sulfur dioxide dry deposition to forests: Observations and model evaluation, J. Geophys. Res.-Atmos., 105, 15365-15377, 2000.

Fischer, M. L. and Littlejohn, D.: Ammonia at Blodgett Forest, Sierra Nevada, USA, Atmos. Chem. Phys. Discuss., 7, 14139-14169, 2007, http://www.atmos-chem-physdiscuss.net/7/14139/2007/.

Flocke, F., Volz-Thomas, A., Buers, H. J., Patz, W., Garthe, H. J., and Kley, D.: Long-term measurements of alkyl nitrates in southern Germany 1. General behavior and seasonal and diurnal variation, J. Geophys. Res.-Atmos., 103, 5729-5746, 1998.

Fountoukis, C., Nenes, A., Sullivan, A., Weber, R., Vanreken, T., Fischer, M., Matias, E., Moya, M., Farmer, D. K., and Cohen, R. C.: Thermodynamic characterization of Mexico City aerosol during MILAGRO 2006, Atmos. Chem. Phys. Discuss., 7, 9203-9233, 2007, http://www.atmos-chem-physdiscuss.net/7/9203/2007/.

Fried, A., McKeen, S., Sewell, S., Harder, J., Henry, B., Goldan, P., Kuster, W., Williams, E., Baumann, K., Shetter, R., and Cantrell, C.: Photochemistry of formaldehyde during the 1993 Tropospheric OH Photochemistry Experiment, J. Geophys. Res.Atmos., 102, 6283-6296, 1997.

Fuentes, J. D., Lerdau, M., Atkinson, R., Baldocchi, D., Bottenheim, J. W., Ciccioli, P., Lamb, B., Geron, C., Gu, L., Guenther, A., Sharkey, T. D., and Stockwell, W.: Biogenic hydrocarbons in the atmospheric boundary layer: A review, B. Am. Meteor. Soc., 81, 1537-1575, 2000.

Giacopelli, P., Ford, K., Espada, C., and Shepson, P. B.: Comparison of the measured and simulated isoprene nitrate distributions above a forest canopy, J. Geophys. Res.-Atmos., 110, D01304, doi:10.1029/2004JD005123, 2005.

Goldstein, A. H., Hultman, N. E., Fracheboud, J. M., Bauer, M. R., Panek, J. A., Xu, M., Qi, Y., Guenther, A. B., and Baugh, W.: Effects of climate variability on the carbon dioxide, water, and sensible heat fluxes above a ponderosa pine plantation in the Sierra Nevada (CA), Agric. For. Meteorol., 101, 113-129, 2000.

Goldstein, A. H., and Schade, G. W.: Quantifying biogenic and anthropogenic contributions to acetone mixing ratios in a rural environment, Atmos. Environ., 34, 4997-5006, 2000.

Grossenbacher, J. W., Couch, T., Shepson, P. B., Thornberry, T., Witmer-Rich, M., Carroll, M. A., Faloona, I., Tan, D., Brune, W., Ostling, K., and Bertman, S.: Measurements of isoprene nitrates above a forest canopy, J. Geophys. Res.-Atmos., 106, 2442924438, 2001.

Grossenbacher, J. W., Barket, D. J., Shepson, P. B., Carroll, M. A., Olszyna, K., and Apel, E.: A comparison of isoprene nitrate concentrations at two forest-impacted sites, J. Geophys. Res.Atmos., 109, D11311, doi:10.1029/2003JD003966, 2004.
Hauglustaine, D. A., Madronich, S., Ridley, B. A., Walega, J. G., Cantrell, C. A., Shetter, R. E., and Hubler, G.: Observed and model-calculated photostationary state at Mauna Loa observatory during MLOPEX 2, J. Geophys. Res.-Atmos., 101, 1468114696, 1996.

Herman, D. J., Halverson, L. J., and Firestone, M. K.: Nitrogen dynamics in an annual grassland: Oak canopy, climate, and microbial population effects, Ecol. Appl., 13, 593-604, 2003.

Holzinger, R., Lee, A., McKay, M., and Goldstein, A. H.: Seasonal variability of monoterpene emission factors for a Ponderosa pine plantation in California, Atmos. Chem. Phys., 6, 1267-1274, 2006, http://www.atmos-chem-phys.net/6/1267/2006/.

Horii, C. V.: Tropospheric reactive nitrogen speiciation, deposition, and chemistry at Harvard Forest, Ph.D. thesis, Department of Earth and Planetary Sciences, Harvard University, Cambridge, 148 pp., 2002.

Horowitz, L. W., Fiore, A. M., Milly, G. P., Cohen, R. C., Perring, A., Wooldridge, P. J., Hess, P. G., Emmons, L. K., and Lamarque, J.-F.: Observational constraints on the chemistry of isoprene over the eastern U.S., J. Geophys. Res.-Atmos., 112, D12S08, doi:10.1029/2006JD007747, 2007.

Kleinman, L., Lee, Y. N., Springston, S. R., Nunnermacker, L., Zhou, X. L., Brown, R., Hallock, K., Klotz, P., Leahy, D., Lee, J. H., and Newman, L.: Ozone formation at a rural site in the Southeastern United States, J. Geophys. Res.-Atmos., 99, 3469-3482, 1994.

Kroll, J. H., Ng, N. L., Murphy, S. M., Flagan, R. C., and Seinfeld, J. H.: Secondary organic aerosol formation from isoprene photooxidation, Environ. Sci. Technol., 40, 1869-1877, 2006.

Kurpius, M. R., McKay, M., and Goldstein, A. H.: Annual ozone deposition to a Sierra Nevada ponderosa pine plantation, Atmos. Environ., 36, 4503-4515, 2002.

Kurpius, M. R., Panek, J. A., Nikolov, N. T., McKay, M., and Goldstein, A. H.: Partitioning of water flux in a Sierra Nevada ponderosa pine plantation, Agric. For. Meteorol., 117, 173-192, 2003.

LaFranchi, B. W., Wolfe, G. M., Thornton, J. A., Browne, E. C., Min, K. E., Wooldridge, P. J., Cohen, R. C., McKay, M., Goldstein, A. H., Gilman, J. B., Welsh-Bon, D., Kuster, W. C., deGouw, J. A., Mao, J., Ren, X., Chen, Z., and Brune, W. H.: Closing the peroxy acetyl (PA) radical budget: observations of acyl peroxy nitrates (PAN, PPN, and MPAN) during BEARPEX 2007, Eos Trans. AGU, 89(53), Fall Meet. Suppl., San Francisco, USA, 15-19 December 2008, A41F-0188, 2008.

Lamanna, M. S. and Goldstein, A. H.: In situ measurements of $\mathrm{C}_{2}-\mathrm{C}_{10}$ volatile organic compounds above a Sierra Nevada ponderosa pine plantation, J. Geophys. Res.-Atmos., 104, $21247-$ 21262, 1999.

Lee, A., Schade, G. W., Holzinger, R., and Goldstein, A. H.: A comparison of new measurements of total monoterpene flux with improved measurements of speciated monoterpene flux, Atmos. Chem. Phys., 5, 505-513, 2005, http://www.atmos-chem-phys.net/5/505/2005/.

Lefer, B. L., Talbot, R. W., and Munger, J. W.: Nitric acid and ammonia at a rural northeastern U.S. site, J. Geophys. Res.-Atmos., 104, 1645-1661, 1999.

Lunden, M., Black, D., and Brown, N.: Characterizing the formation of secondary organic aerosols, Interim Report. Environmental Energy Technologies Division, Lawrence Berkeley National 
Laboratory. eScholarship Repository, University of California, http://repositories.cdlib.org/lbnl/LBNL-54446, 2004.

Mihele, C. M. and Hastie, D. R.: Radical chemistry at a forested continental site: Results from the PROPHET 1997 campaign, J. Geophys. Res., 108, 4450, doi:10.1029/2002JD002888, 2003.

Minejima, C.: Nitrogen Oxide Chemistry at Night: Novel Instrumentation Applied to Field Measurements in California, Ph.D. thesis, Department of Chemistry, University of California, Berkeley, CA, USA, 2008.

Munger, J. W., Wofsy, S. C., Bakwin, P. S., Fan, S. M., Goulden, M. L., Daube, B. C., Goldstein, A. H., Moore, K. E., and Fitzjarrald, D. R.: Atmospheric deposition of reactive nitrogen oxides and ozone in a temperate deciduous forest and a subarctic woodland 1. Measurements and Mechanisms, J. Geophys. Res.Atmos., 101, 12639-12657, 1996.

Munger, J. W., Fan, S. M., Bakwin, P. S., Goulden, M. L., Goldstein, A. H., Colman, A. S., and Wofsy, S. C.: Regional budgets for nitrogen oxides from continental sources: Variations of rates for oxidation and deposition with season and distance from source regions, J. Geophys. Res.-Atmos., 103, 8355-8368, 1998.

Murphy, J. G., Thornton, J. A., Wooldridge, P. J., Day, D. A., Rosen, R. S., Cantrell, C., Shetter, R. E., Lefer, B., and Cohen, R. C.: Measurements of the sum of $\mathrm{HO}_{2} \mathrm{NO}_{2}$ and $\mathrm{CH}_{3} \mathrm{O}_{2} \mathrm{NO}_{2}$ in the remote troposphere, Atmos. Chem. Phys., 4, 377-384, 2004, http://www.atmos-chem-phys.net/4/377/2004/.

Murphy, J. G., Day, A., Cleary, P. A., Wooldridge, P. J., and Cohen, R. C.: Observations of the diurnal and seasonal trends in nitrogen oxides in the western Sierra Nevada, Atmos. Chem. Phys., 6, 5321-5338, 2006,

http://www.atmos-chem-phys.net/6/5321/2006/.

Murphy, J. G., Day, D. A., Cleary, P. A., Wooldridge, P. J., Millet, D. B., Goldstein, A. H., and Cohen, R. C.: The weekend effect within and downwind of Sacramento: Part 1. Observations of ozone, nitrogen oxides, and VOC reactivity, Atmos. Chem. Phys., 7, 5327-5339, 2007,

http://www.atmos-chem-phys.net/7/5327/2007/.

Neuman, J. A., Huey, L. G., Ryerson, T. B., and Fahey, D. W.: Study of inlet materials for sampling atmospheric nitric acid, Environ. Sci. Technol., 33, 1133-1136, 1999.

O’Brien, J. M., Shepson, P. B., Muthuramu, K., Hao, C., Niki, H., Hastie, D. R., Taylor, R., and Roussel, P. B.: Measurements of alkyl and multifunctional organic nitrates at a rural site in Ontario, J. Geophys. Res., 100, 22795-22804, 1995.

O’Brien, J. M., Shepson, P. B., Wu, Q., Biesenthal, T., Bottenheim, J. W., Wiebe, H. A., Anlauf, K. G., and Brickell, P.: Production and distribution of organic nitrates, and their relationship to carbonyl compounds in an urban environment, Atmos. Environ., 31, 2059-2069, 1997.

Ostling, K., Kelly, B., Bird, S., Bertman, S., Pippin, M., Thornberry, T., and Carroll, M. A.: Fast-turnaround alkyl nitrate measurements during the PROPHET 1998 summer intensive, J. Geophys. Res., 106, 24439-24449, 2001.

Parrish, D. D., Norton, R. B., Bollinger, M. J., Liu, S. C., Murphy, P. C., Albritoon, D. L., Fehsenfeld, F. C., and Heubert, B. J.: Measurements of $\mathrm{HNO}_{3}$ and $\mathrm{NO}_{3}$ particulates at a rural site in the Colorado mountains, J. Geophys. Res.-Atmos., 91, 5379-5393, 1986.

Parrish, D. D., Buhr, M. P., Trainer, M., Norton, R. B., Shimshock, J. P., Fehsenfeld, F. C., Anlauf, K. G., Bottenheim, J. W., Tang,
Y. Z., Wiebe, H. A., Roberts, J. M., Tanner, R. L., Newman, L., Bowersox, V. C., Olszyna, K. J., Bailey, E. M., Rodgers, M. O., Wang, T., Berresheim, H., Roychowdhury, U. K., and Demerjian, K. L.: The total reactive oxidized nitrogen levels and the partitioning between the individual species at six rural sites in eastern North America, J. Geophys. Res.-Atmos., 98, 2927-2939, 1993.

Patchen, A. K., Pennino, M. J., Kiep, A. C., and Elrod, M. J.: Direct kinetics study of the product-forming channels of the reaction of isoprene-derived hydroxyperoxy radicals with NO, Int. J. Chem. Kin., 39, 353-361, doi:10.1002/kin.20248, 2007.

Paulot, F., Crounse, J. D., Kjaergaard, H. G., Kroll, J. H., Seinfeld, J. H., and Wennberg, P. O.: Isoprene photooxidation mechanism: Resonance channels and implications for the production of nitrates and acids, Atmos. Chem. Phys. Discuss., 8, 14643-14716, 2008, http://www.atmos-chem-phys-discuss.net/8/14643/2008/.

Pérez, I. M., Wooldridge, P. J., and Cohen, R. C.: Laboratory evaluation of a novel thermal dissociation chemiluminescence method for in situ detection of nitrous acid, Atmos. Environ., 41, 39934001, 2007.

Pérez, I. M.: The photochemical evolution of the Sacramento urban plume: A guide to controlling ozone now and in a warmer climate, Ph.D. thesis, Department of Chemistry, University of California, Berkeley, CA, USA, 2008.

Pérez, I. M. and Cohen, R. C.: A Lagrangian model of the chemical composition of an urban plume 1: nitrogen oxides, in preparation, 2009.

Perring, A. E., Bertram, T. H., Wooldridge, P. J., Fried, A., Heikes, B. G., Dibb, J., Crounse, J. D., Wennberg, P. O., Blake, N. J., Brune, W. H., Blake, D. R., and Cohen, R. C.: Airborne observations of total $\mathrm{RONO}_{2}$ : new constraints on the yield and lifetime of isoprene nitrates, Atmos. Chem. Phys. Discuss., 8, 1231312341, 2008, http://www.atmos-chem-phys-discuss.net/8/12313/2008/.

Roberts, J. M., Tanner, R. L., Newman, L., Bowersox, V. C., Bottenheim, J. W., Anlauf, K. G., Brice, K. A., Parrish, D. D., Fehsenfeld, F. C., Buhr, M. P., Meagher, J. F., and Bailey, E. M.: Relationships between pan and ozone at sites in eastern North America, J. Geophys. Res.-Atmos., 100, 22821-22830, 1995.

Roberts, J. M., Stroud, C. A., Jobson, B. T., Trainer, M., Hereid, D., Williams, E., Fehsenfeld, F., Brune, W., Martinez, M., and Harder, H.: Application of a sequential reaction model to PANs and aldehyde measurements in two urban areas, Geophys. Res. Lett., 28, 4583-4586, 2001.

Romero, M. T. B., Blitz, M. A., Heard, D. E., Pilling, M. J., Price, B., Seakins, P. W., and Wang, L. M.: Photolysis of methylethyl, diethyl and methylvinyl ketones and their role in the atmospheric HOx budget, Faraday Discussions, 130, 73-88, doi:10.1039/b419160a, 2005.

Rosen, R. S., Wood, E. C., Wooldridge, P. J., Thornton, J. A., Cohen, R. C., Williams, E. J., Roberts, J. M., Jobson, T. B., and Kuster, W.: Observations of total alkyl nitrates during TEXAQS2000, AGU Fall Meeting, San Francisco, USA, 6-10 December 2002, Conference Poster, 2002.

Rosen, R. S., Wood, E., Wooldridge, P. J., Thornton, J. A., Day, D. A., Kuster, B., Williams, E. J., Jobson, B. T., and Cohen, R. C.: Observations of total alkyl nitrates during Texas Air Quality Study 2000: Implications for $\mathrm{O}_{3}$ and alkyl nitrate photochemistry, J. Geophys. Res.-Atmos., 107, D07303, doi:10.1029/2003JD004227, 2004. 
Ryerson, T. B., Huey, L. G., Knapp, K., Neuman, J. A., Parrish, D. D., Sueper, D. T., and Fehsenfeld, F. C.: Design and initial characterization of an inlet for gas-phase $\mathrm{NO}_{\mathrm{y}}$ measurements from aircraft, J. Geophys. Res.-Atmos., 104, 5483-5492, 1999.

Sander, S. P., Friedl, R. R., Ravishankara, A. R., Golden, D. M., Kolb, C. E., Kurylo, M. J., Molina, M. J., Moortgat, G. K., Heller-Rudek, H., Finlayson-Pitts, B. J., Wine, P. H., Huie, R. E., and Orkin, V. L.: Chemical kinetics and photochemical data for use in atmospheric studies, Evaluation Number 15, National Aeronautics and Space Administration; Jet Propulsion Laboratory California Institute of Technology, Pasadena, California, USA, 523 pp., 2006.

Schade, G. W. and Crutzen, P. J.: CO emissions from degrading plant matter (II). Estimate of a global source strength, Tellus Series B-Chemical and Physical Meteorology, 51, 909-918, 1999.

Schade, G. W., Goldstein, A. H., and Lamanna, M. S.: Are monoterpene emissions influenced by humidity?, Geophys. Res. Lett., 26, 2187-2190, 1999a.

Schade, G. W., Hofmann, R. M., and Crutzen, P. J.: CO emissions from degrading plant matter (I). Measurements, Tellus B, 51, 889-908, 1999b.

Schade, G. W. and Goldstein, A. H.: Fluxes of oxygenated volatile organic compounds from a ponderosa pine plantation, J. Geophys. Res.-Atmos., 106, 3111-3123, 2001.

Schneider, M., Luxenhofer, O., Deissler, A., and Ballschmiter, K.: C-1-C-15 alkyl nitrates, benzyl nitrate, and bifunctional nitrates: Measurements in California and South Atlantic air and global comparison using $\mathrm{C} 2 \mathrm{Cl} 4$ and $\mathrm{CHBr} 3$ as marker molecules, Environ. Sci. Technol., 32, 3055-3062, 1998.

Seaman, N. L., Stauffer, D. R., and Lariogibbs, A. M.: A multiscale four-dimensional data assimilation system applied in the San Joaquin Valley during SARMAP .1. Modeling design and basic performance characteristics, J. Appl. Meteorol., 34, 17391761, 1995.

Shepson, P. B., Hastie, D. T., So, K. W., and Schiff, H. I.: Relationship between PAN, PPN, and $\mathrm{O}_{3}$ at urban and rural sites in Ontario, Atmos. Environ., 26A, 1259-1270, 1992.

Singh, H. B., Herlth, D., Ohara, D., Zahnle, K., Bradshaw, J. D., Sandholm, S. T., Talbot, R., Crutzen, P. J., and Kanakidou, M.: Relationship of peroxyacetyl nitrate to active and total odd nitrogen at northern high latitudes: Influence of reservoir species on $\mathrm{No}_{\mathrm{x}}$ and $\mathrm{O}_{3}$, J. Geophys. Res.-Atmos., 97, 16523-16530, 1992.

Smyth, S. B., Sandholm, S. T., Bradshaw, J. D., Talbot, R. W., Blake, D. R., Blake, N. J., Rowland, F. S., Singh, H. B., Gregory, G. L., Anderson, B. E., Sachse, G. W., Collins, J. E., and Bachmeier, A. S.: Factors influencing the upper free tropospheric distribution of reactive nitrogen over the South Atlantic during the TRACE A experiment, J. Geophys. Res.-Atmos., 101, 2416524186, 1996.
Spaulding, R. S., Schade, G. W., Goldstein, A. H., and Charles, M. J.: Characterization of secondary atmospheric photooxidation products: Evidence for biogenic and anthropogenic sources, J. Geophys. Res., 108, 4247, doi:10.1029/2002JD002478, 2003.

Sprengnether, M., Demerjian, K. L., Donahue, N. M., and Anderson, J. G.: Product analysis of the $\mathrm{OH}$ oxidation of isoprene and 1,3-butadiene in the presence of NO, J. Geophys. Res.-Atmos., 107, 4268, doi:10.1029/2001JD000716, 2002.

Thornberry, T., Carroll, M. A., Keeler, G. J., Sillman, S., Bertman, S. B., Pippin, M. R., Ostling, K., Grossenbacher, J. W., Shepson, P. B., Cooper, O. R., Moody, J. L., and Stockwell, W. R.: Observations of reactive oxidized nitrogen and speciation of $\mathrm{NO}_{\mathrm{y}}$ during the PROPHET summer 1998 intensive, J. Geophys. Res.Atmos., 106, 24359-24386, 2001.

Thornton, J. A., Wooldridge, P. J., and Cohen, R. C.: Atmospheric $\mathrm{NO}_{2}$ : In situ laser-induced fluorescence detection at parts per trillion mixing ratios, Anal. Chem., 72, 528-539, 2000.

Thornton, J. A., Wooldridge, P. J., Cohen, R. C., Martinez, M., Harder, H., Brune, W. H., Williams, E. J., Fehsenfeld, F. C., Hall, S. R., Shetter, R. E., Wert, B. P., and Fried, A.: Observations of ozone production rates as a function of $\mathrm{NO}_{2}$ abundances and $\mathrm{HO}_{\mathrm{x}}$ production rates in the Nashville urban plume, J. Geophys. Res.-Atmos., 107, 4146, doi:10.1029/2001JD000932, 2002.

Trainer, M., Buhr, M. P., Curran, C. M., Fehsenfeld, F. C., Hsie, E. Y., Liu, S. C., Norton, R. B., Parrish, D. D., Williams, E. J., Gandrud, B. W., Ridley, B. A., Shetter, J. D., Allwine, E. J., and Westberg, H. H.: Observations and modeling of the reactive nitrogen photochemistry at a rural site, J. Geophys. Res.-Atmos., 96, 3045-3063, 1991.

Tuazon, E. C., and Atkinson, R.: A product study of the gas-phase reaction of isoprene with the $\mathrm{OH}$ radical in the presence of $\mathrm{NO}_{\mathrm{x}}$, Int. J. Chem. Kin., 22, 1221-1236, 1990.

UCAR/NCAR/ACD: Tropospheric Ultraviolet and Visible (TUV) Radiation Model: http://cprm.acd.ucar.edu/Models/TUV/, 2006.

Wildt, J., Kley, D., Rockel, A., Rockel, P., and Segschneider, H. J.: Emission of NO from several higher plant species, J. Geophys. Res.-Atmos., 102, 5919-5927, 1997.

Woidich, S., Froescheis, O., Luxenhofer, O., and Ballschmiter, K.: El- and NCl-mass spectrometry of arylalkyl nitrates and their occurrence in urban air, Fres. J.f Anal. Chem., 364, 91-99, 1999.

Zellweger, C., Ammann, M., Buchmann, B., Hofer, P., Lugauer, M., Ruttimann, R., Streit, N., Weingartner, E., and Baltensperger, U.: Summertime $\mathrm{NO}_{\mathrm{y}}$ speciation at the Jungfraujoch, $3580 \mathrm{~m}$ above sea level, Switzerland, J. Geophys. Res., 105, 6655-6667, 2000. 